\title{
Trójai faló és fügefalevél: a populizmus szerepe a globális demokráciakrízisben és posztmodern autokráciákban ${ }^{1}$
}

\author{
BENEDEK ISTVÁN²
}

\begin{abstract}
ABSZTRAKT
Állításom szerint a populizmus lehet az a kapocs, amely segíthet megfelelőbb keretben értelmezni nem csupán a globális demokráciakrízist, hanem az új típusú autokráciák térnyerését és mindennapi múködését. Az állítás alátámasztása érdekében előbb ezen jelenségek térhódításának jellegzetességeit vizsgáltam meg, majd a közöttük lévő kapcsolat természetével foglalkoztam, különös tekintettel az új típusú autokráciák stabilitásának vizsgálatára, amelyben érvelésem szerint a populizmus kulcsszerepet tölt be. A demokrácia és a képviselet egy autokratikus értelmezéseként felfogott populizmus, mint egy trójai faló, különösen nagy veszélyt jelent a demokráciákra, mindenekelött a homogénnek képzelt nép egységes akaratának és a közjó meghatározásának kisajátítására törekvő, megcáfolhatatlan morális képviseleti igénye miatt. Másfelől a populizmus az új típusú, formálisan ugyan többpárti választásokkal operáló posztmodern autokráciák számára a politikai versengés szisztematikusan eltorzított, így csupán korlátozott jellegét, valamint a rendszeren belüli újabb és újabb autokratikus tendenciák elfedését és legitimálását szolgálhatja. Mivel egy radikális, a modern autokráciákat idéző hatalmi fordulat túlságosan költséges lenne, a kvázi-demokratikus legitimációt biztosító manipulált, de többpárti választásokra és másfajta plebiszciter technikákra nélkülözhetetlen szerep hárul a posztmodern autokráciák számára, amelyekben a konszolidált politikai versenyt élet-halál harccá transzformáló és egyéb kognitív funkciókat ellátó populizmus központi szerepet tölthet be. Azaz a populista autokrácia - mint a posztmodern autokráciák egy paradigmatikus típusa - jelensége sokáig velünk maradhat, újabb és újabb feladatokat adva ezzel a múködésükkel foglalkozó kutatók számára.
\end{abstract}

KULCSSZAVAK: demokrácia, autokrácia, populizmus, képviselet, legitimáció

\footnotetext{
${ }^{1}$ A tanulmány az Új Nemzeti Kiválóság Program (ÚNKP-19-3) keretében, valamint NKFIH-támogatással (projekt témaszáma: K-128139) készült.

2 Társadalomtudományi Kutatóközpont Politikatudományi Intézet, Magyar Tudományos Akadémia Kiváló Kutatóhely, ELTE ÁJK Politikatudományi Doktori Iskola, e-mail: benedek.istvan@tk.mta.hu
} 


\section{TANULMÁNY}

\section{ABSTRACT \\ Trojan horse and fig leaf: the role of populism in the global crisis of democracy and the postmodern autocracies}

It is my contention that populism could be an appropriate framework to understand and link the phenomena of global crisis of democracy and spread of postmodern autocracies. In order to substantiate this claim with the method of literature review, I have examined first the characteristics of these phenomena and then I have focused the nature of relationship between them, in particular with regard to the complex system of stability of new types of autocracies, in which, I think, populism playing a key role. Populism, understood it as an autocratic interpretation of democracy and representation, could be a particularly dangerous Trojan horse for democracy. Above all, because of its idea of a single, homogeneous and authentic people that can be genuinely represented only by populists, and because of this representative claim is a moralized form of antipluralism. In addition, populism is also an important feature of postmodern autocracies, especially of electoral autocracy. By means of populism, it is possible for these regimes to camouflage and even legitimise the autocratic trends and exercise of power, as well as the creation an uneven playing field for political contestation behind their formally multi-party elections and democratic façade. As a radical turn towards traditional forms of autocracies would be too expensive, postmodern autocrats need manipulated multi-party elections and other plebiscite techniques that could serve as quasi-democratic legitimation, as well as populism that could transform political contestation to a life-and-death struggle and, provides other important cognitive functions. Therefore, populist autocracy, as a paradigmatic type of postmodern autocracies, will remain with us for a long time, giving more and more tasks to researchers involved in them.

KEYWORDS: democracy, autocracy, populism, representation, legitimacy

\section{Bevezetés}

A tanulmányban a globális demokráciakrízis, a populizmus és az új típusú autokráciák jelenségeit vizsgálom, különös tekintettel a közöttük lévő kapcsolat természetére. Állításom szerint ugyanis a fenti jelenségek globális térhódításának magyarázatai jelentős részben a közöttük lévő kapcsolatban keresendőek, méghozzá az egymást kiegészítő és kölcsönösen erősítő természetük okán. Jelentősen erősíti ezt a hipotézist az a tény, hogy nem sokkal tágabb térségünk, Közép- és Kelet-Európa rendszerváltásait követően meglehetősen szimultán módon indult meg több, a fenti jelenségekhez kapcsolódó tudományos diskurzus, sokszor explicit átfedésekkel is az egyes témák között. Az is összeköti ezeket a diskurzusokat, hogy 1989 „tranzitológiai” optimizmusát követően mindhárom területen egyre szkeptikusabbá vált a kutatók hangvétele, ezzel párhuzamosan pedig egyre inkább tűnt úgy, hogy Fukuyama (1992) híres tézisével szemben a történelem egyáltalán nem „ért véget”, hiszen a „létező” liberális demokráciák egyre nagyobb belső és külső kihívásokkal kell, hogy szembenézzenek. Az elmúlt három évtized demokráciaelméleti és összehasonlító politikatudományi munkáinak zöme a fenti, egyre pesszimistább alapállásból kiin- 


\section{TANULMÁNY}

dulva elemzi a konszolidált képviseleti demokráciák gyarapodó belső kríziseit és kritikáit, valamint a populizmus térhódítását és az új típusú autokráciák elterjedését.

A demokráciák erősödő belső feszültségei kapcsán többek között olyan tendenciákra mutattak rá neves szerzők, mint a politikai folyamatok állampolgárok általi követhetőségének és átláthatóságának gyengülése (Canovan 2002, Reybrouck 2010, 2016), a jelentős mértékű állampolgári passzivitás és apátia mellett egyre erősödő általános depolitizáció és top-down politizálás (Rosanvallon 2008), vagy a pártok folyamatosan mélyülő válsága és eljelentéktelenedése (Mair 2002, 2013). Jelentős kritika érte a demokráciák „túlzott intézményközpontúságát” és a létrejövő poszt-politikai állapotot (Mouffe 1993, Ranciere 1999), amely nyomán a populizmus bizonyos szempontból az „antidemokratikus liberalizmusra” (Mudde - Rovira Kaltwasser 2017) és az intézményes „támfalak” és a technokrácia túltengésére (Müller 2016) adott válasznak is tekinthető. Kiemelkedő művek születtek a politikát egyre inkább átható perszonalizáció, mediatizáció és tablodizáció jelenségeiről, amely nyomán a demokratikus választások és a mindennapi politika egyre inkább afféle politikai színházi előadások kiüresedett imázsküzdelmének tűnik sokak számára (Manin 1994, 1997, Crouch 2004).

Az ilyen és hasonló belső feszültségeken túl a demokráciák külső kihívásai között a kutatók szemében az első számú helyen a - leginkább a demokratizálódás újabb ellenhullámaként (Huntington 1991) értelmezett - autokratizálódás és az ennek nyomán létrejövő új típusú autokráciák vizsgálata áll. Az 1990-es évektől megsokasodtak a megváltozott természetű autokráciákkal és hibrid rezsimekkel, illetve azok stabilizációs mechanizmusaival foglalkozó munkák (Karl 1995, O’Donnell 1996, Zakaria 1997, Diamond 2002, 2019, Carothers 2002, Morlino 2009, Bogaards 2009, Levitsky - Way 2002, 2010, Schedler 2002, 2013, Cassani 2014, Foa 2018, Guriev - Treisman 2015, 2019). A rendkívül szerteágazó irodalom elsősorban a politikai versengést korlátozó különféle stratégiákat és „intézményes trükköket” vizsgálja (Levitsky - Ziblatt 2018), bár újabban sok figyelem irányul az „autokratikus legitimáció" (Gerschewski 2018) témájára is.

Véleményem szerint ezen a ponton kapcsolhatóak össze a fenti jelenségek és a hozzájuk kapcsolódó kutatási irányzatok, méghozzá a populizmus segítségével. Már önmagában az is beszédes, hogy az 1990-es évektől a populizmus-irodalom is szintet lépett volumenét tekintve (Urbinati 1998, 2013, Canovan 1999, 2002, Mény Surel 2002, Mudde 2004, Laclau 2011, Abts - Rummens 2007), amely az utóbbi évtizedben a politikatudomány talán legkutatottabb témájává vált (Reybrouck 2010, Urbinati 2013, Mudde - Rovira Kaltwasser 2017, Moffitt - Tormey 2014, Moffitt 2016, Pappas 2014, 2018, Judis 2016, Müller 2016, Rovira Kaltwasser et al. 2017, de la Torre 2018). Habár már arról is komoly vita zajlik, hogy egyáltalán mit is kell a populizmus kifejezés alatt érteni, azonban abban a legtöbb kutató egyetért, hogy a jelenség kifejezetten veszélyes is lehet a demokráciákra nézve, köszönhetően anti- 


\section{TANULMÁNY}

elitista és antipluralista természetének, valamint a démosz kizárólagos és morálisan cáfolhatatlan képviseleti igénye miatt. Ez ugyanis könnyedén vezethet olyan mértékű extrém polarizációhoz, amely a demokratikus működéshez szükséges minimális konszenzust is alááshatja. Ez pedig kifejezetten kompatibilisnek látszik a különféle autokratikus rezsimekkel, amelyre a szakirodalomban megjelenő autoriter populizmus (Norris - Inglehart 2019, Bugaric - Kuhelj 2018, Bugaric 2019) és populista autoritarianizmus (Butler 2018) fogalmak is elkezdtek reflektálni.

Jelen tanulmányban magam is amellett szeretnék érvelni, hogy a fenti jelenségek szorosan összefüggenek, és a populizmus lehet az a kapocs, amely segíthet megfelelőbb keretben értelmezni mind az egyre nyilvánvalóbb demokráciakrízist, mind pedig az új típusú autokráciák térnyerését és mindennapi működését. Az állítás alátámasztása érdekében előbb ezért ezen jelenségek térhódításának jellegzetességeit vizsgálom meg néhány releváns, hozzájuk kapcsolódó szakirodalom segítségével, majd a közöttük lévő kapcsolat természetével foglalkozom, különös tekintettel az új típusú autokráciák komplex stabilizációs rendszerére, amelyben érvelésem szerint a populizmus kulcsszerepet tölt be. Végezetül az összefoglalás mellett kitérek néhány további lehetséges kutatási irányra is.

\section{Baljós árnyak}

\section{GLOBÁLIS DEMOKRÁCIAKRÍZIS...}

Az elmúlt néhány évtizedben számtalan munka született azzal kapcsolatban, hogy a képviseleti tömegdemokráciák - második világháborút követő néhány évtizedre jellemző relatív háborítatlan - legitimációja egyre komolyabb kihívásokkal küzd. Véleményem szerint ezek a jelenségek a 2000-es évek végére, a 2008-as globális pénzügyi válság hatásaival értek el egy kritikus tömeget, amely többek között az addig is jelen lévő populizmusnak nyitott korábban el nem ért távlatokat, ezzel is komoly változásokat előidézve mind a demokráciákban, mind az autokráciákban. A demokráciák elmúlt évtizedekbeli működésével kapcsolatban a legfőbb kritikák a túlzottan intézményközpontúvá és túlbürokratizálttá váló mindennapi múködést érték, amelyek elsősorban a korábbi világháborús tapasztalatok nyomán a népszuverenitást kordába záró intézményes „támfalak” és a technokrácia túltengését jelentik a gyakorlatban, és amelyek jelentősen csökkentették az állampolgárok politikai részvételét (Müller 2016). Az intézmények eluralkodásával párhuzamosan a hagyományos pártok identitásvesztése vált meghatározóvá, hiszen azok egyre kevésbé nyújtanak egymástól jól elkülöníthető, valódi alternatívákat a választópolgárok szemében (Mair 2002, Mouffe 2018). De nem csupán a pártok, hanem általában az állampolgárokat a nagypolitikával összekötő köztes intézmények válsága is megfigyelhető, különösen a régiónkban (Ágh 2017, 2018). A demokráciakrízis fontos további eleme az 


\section{TANULMÁNY}

a normatív legitimációs deficit, amelyet a Szovjetunió összeomlása jelentett a demokrácia számára. Így utóbbi működése és teljesítménye, miután elveszítette „főellenségét", már nem a szocialista berendezkedés alternatívájaként került elbírálásra, hanem különféle, sokkal nehezebben teljesíthető elméleti modelleknek és elvárásoknak lett kitéve. Ehhez hasonlóan az edukáltság általános növekedése szintén emelte az állampolgári elvárásokat a saját politikai berendezkedésük irányába (Mudde 2004).

A sok vonatkozásában nemzetközivé váló intézményes komplexitásnövekedés nemzetállami szuverenitásvesztéssel is együtt járt, amely nyomán a demokráciákban egyre nehezebbé vált elképzelni és megragadni a hatalom tényleges helyét, amely megnövelte a feszültséget azok között a demokratikus alapelvek között, miszerint a "hatalom a népé”, illetve egyúttal a "hatalom senkié” (Canovan 2002, Lefort 1986). Rosanvallon (2008) „ellendemokrácia” koncepciója élesen mutat rá, hogy önmagában az intézmények nem elegendőek, azt körbe kell, hogy vegye az azokat nem csupán felügyelni, hanem megvédeni is hajlandó társadalmi attitűd és gondolkodásmód, amely nem csupán kiegészíti a hagyományos intézményes eszköztárat, hanem megnöveli annak hatóerejét is. Ehelyett a túlzottan intézményorientálttá és depolitizált politikai közösségekkel jellemezhető liberális demokráciák bizalmi és legitimációs válságba kerültek (Manin 1997, Mair 2013), amely - tovább gerjesztve egy hatékonyságbeli krízissel - egy harsány, a reszponzivitás-deficitnek szóló, tömeges neheztelésben fejeződik ki (Reybrouck 2016). Ezzel kapcsolatban látványossá vált a demokratikus hatalom transzparenciájának mértéke és a társadalom politikához való intézményes hozzáférése és aktivitása közötti trade-off, amelyben a demokráciák egyre nehezebben tudnak egyensúlyozni, és amelyet a populista politikusok egyre könnyebben és sikeresebben használhatnak ki, egyszerre kínálva felhatalmazást és transzparenciát személyükben (Canovan 2002). Így a populizmus az intézmények általi elszámoltathatóság első számú megkérdőjelezője (Papadopoulos 2002). A demokráciák mind látványosabb kiüresedéséért felelős politikai változások a „millenniumi trend” kifejezéssel is megragadhatóak, amely többek között „a szavazói viselkedés növekvő volatilitását, a törésvonalak »kiolvadását«, a pártok és a parlamentek szerepének hanyatlását, a politika mediatizációját, perszonalizációját és "prezidencializációját«" foglalja magában (Körösényi - Gyulai 2019: 168).

Ezen folyamatok mellett egyre nagyobb figyelem összpontosul a politikai polarizáció növekedésére, amely extrém formáiban képes teljes mértékben kiiktatni az állampolgárok kompromisszumkészségét és a démosz egységét, aláásva ezzel a demokratikus politizálás lehetőségét. Az extrém mértékű polarizáció ugyanis nem csupán a demokrácia kemény védőkorlátait jelentő intézményeket állítja hadi üzemmódba, hanem a puha védőkorlátot jelentő demokratikus normákat is megtámadja, amelyek nélkül egyenes az út a „politika védőkorlátok nélküli állapota” felé (Levitsky - Ziblatt 2018). Ha a „pártok ellenfelekből ellenségek lesznek, a politikai versenyből háború lesz, intézményeinkből fegyverek”, akkor az „eredmény egy olyan rendszer 


\section{TANULMÁNY}

létrejötte, amely folyamatosan a válság szélén imbolyog (Levitsky - Ziblatt 2018: 229). Más szavakkal, az extrém mértékú polarizációval kiszabadul egy olyan szellem a palackból, amely agonisztikus és egyéb, demokratikusan kezelhető konfliktusokból beláthatatlan következményekkel járó antagonisztikus, korlátok nélküli konfliktusokat generál, amely aligha kompatibilis a demokráciával. Bár a politikai polarizáció maga is egy sokféle értelemben használt fogalom - amely kapcsán megkülönböztethetjük a választók és a politikai elit törvényhozási, ideológiai, szakpolitikai, érzelmi és kapcsolati polarizációját -, az egyénre jellemző pártos elfogultságnak a politikai közösség szintjén értelmezett erőteljes megjelenése nem csupán a demokráciát, hanem az adott ország gazdasági teljesítményét is gyengíti, például az elszámoltathatóság csökkenésén vagy a korrupció növekedésén keresztül (Patkós 2017).

A helyzetet tovább feszíti a gyorsuló globalizáció jelensége, amely újabb kihívásokat jelent a hagyományosan nemzetállamokra épülő demokráciák működése számára (Merkel 2014). Ehhez kapcsolódóan Colin Crouch (2004) bevezeti a „posztdemokrácia” fogalmát, amelyet a csökkenő transzparencia, a politika top-down és jellemzően szakértő technokraták által történő menedzselése és manipulálása, illetve az imázs-küzdelmekké silányuló választások, valamint az állampolgári tömegek passzív és apatikus hozzáállása jellemez. Véleménye szerint a nyugati demokráciák a jóléti államok leépülésével túljutottak a demokratikus holtpontjukon, így egyfajta parabolaként nem a maximális demokrácia-modellek felé, hanem a posztdemokrácia korszaka felé tartanak. Maga a fogalom - rímelve a később tárgyalandó hibrid rezsimekről szóló irodalomra - a demokrácia és a nem-demokrácia között húzódó mezőre utal, létrejöttének oka pedig a szerző szerint abban rejlik, hogy a „demokrácia egyszerűen nem tud lépést tartani a globális kapitalizmussal” (Crouch 2004: 29). Ugyanezt a fajta „lemaradást” magyarázza Rodrik (2000) a híres „globalizációs trilemma" tézisével, mely szerint nem választhatjuk egyszerre a mélyebb integrációt jelentő hiperglobalizációt, a demokratikus politikát, valamint a nemzetállamiságot, mivel az egyes elemek egymást kizáró természetéből fakadóan ezekből egy időben csupán kettőt lehetséges megvalósítani. A globalizáció jelentette korszakos gazdasági átmenet tehát a nemzetállami keretre épülő demokráciák cselekvőképességét is gyengítette, miközben az ezt jellemzően kritizáló populista üzeneteknek ellenségképet és gyarapodó népszerűséget jelentett.

A globális kapitalizmus demokráciákra veszélyes folyamatait alaposabban is elemzik a kutatók, jellemzően a neoliberalizmus címszó alatt. Ebben a megközelítésben az utóbbi évtizedek globális kapitalizmusaként értelmezett neoliberalizmus a versengő piacoknak az élet minden területére történő expanzióját takarja (Springer et al. 2016, Antal 2019). A probléma ott jelenik meg a demokrácia számára, hogy a neoliberalizmus felmondja a beágyazott liberalizmus, azaz a szabadkereskedelem és a demokratikus államoknak a piacok feletti kontrollja között létesült jóléti kompromisszumot, ezzel megindítva a piacok „nemzeti fennhatóság alóli kiágyazó- 


\section{TANULMÁNY}

dását” (Bruszt - Langbein, 2017). A kulcsintézmények a jóléti államok helyett immár a globális vállalatok lettek (Crouch 2004), amelyek végső soron nem is igazán szabad piacokat szeretnének, mintsem a saját képükre formált piacokat. Ebben a demokratikus nyomástól elszigetelt államnak, mint szabályozó és végrehajtó hatalomnak kulcsszerepe lesz, amelyet a neoliberalizmus a saját érdekei mentén képes újradefiniálni (Bruff 2016), szükség esetén - akár a civil társadalom kárára - meg is erősítve azt (Weyland 1996, Roberts 2014). Így a klasszikus értelmezéssel szemben a neoliberalizmus nem okvetlenül a kisebb állam képében jelenik meg, helyette különféle, a meghatározó piaci szereplők számára kedvező formákban. Ebből következően a neoliberalizmus nem csupán a nemzetállami szuverenitást áshatja alá a különféle globális governance intézményekkel és a pénzügyi központok felé történő eltolódással, hanem erodálhatja magát a demokráciát is (Hickel 2016). Habár vannak demokratikus szempontból pozitív hozadékai is a globalizációnak (például a digitalizáció vagy az állampolgári kommunikációs lehetőségek terén), ugyanakkor a tőke és a vagyon extrém mértékü koncentrációjáért és egyenlőtlen eloszlásáért is felelős, amely társadalmi és gazdasági instabilitást és masszív egyenlőtlenségeket eredményezett (Piketty 2014). Ezáltal megjelent egy új, instabil, globális prekariátus osztály (Standing 2011), amely a „hátrahagyottak” (Judis 2016) populizmusra fogékony dühös tömegeit takarja (Tallár 2017).

\section{...ÉS A POSZTMODERN AUTOKRÁCIÁK FELÍVELÉSE}

Az eddig tárgyalt belső kihívásokon túl a képviseleti tömegdemokráciák szembe kell, hogy nézzenek azzal a ténnyel is, hogy a „hagyományos” diktatúrák letűnését különféle új típusú, posztmodern autokráciák felívelése váltotta fel. Ezzel a fogalommal azokat a rezsimeket jelölöm, amelyek a 20. századra jellemző „modern” elődeikhez képest elsősorban azért tekinthetőek „posztmodernnek”, mert a politikai hatalmat és az autokratikus uralmat általános választójogra épülő többpárti választások (menedzselt) kockázatai mellett gyakorolják. Emiatt ezek a rendszerek már elsősorban nem a szűkre szabott választójog, a pluralista versengés nyílt hiánya (egypártrendszer) vagy a közvetlen fizikai erőszak eszközeivel igyekeznek stabilizálni a hatalmukat, bár elmozdulhatnak ezen irányokba is. Helyette inkább a versenyfeltételek szisztematikus eltorzításával (uneven playing field) korlátozzák a politikai versengést, amely a demokratikus intézményrendszer megkerülését, elfoglalását, kiüresítését és átállítását jelenti a gyakorlatban. A választások intézménye nyomán ezek a rezsimek gyakran populisták egyúttal, de nem szükségszerűen, ahogyan azt Szingapúr példája mutatja.

A posztmodern autokráciák felívelésével párhuzamosan megszűnt az 1990-es évek elejét jellemző eufória és „tranzitológiai optimizmus” (Böcskei - Hajdu 2019), hiszen a demokrácia mára egyre kevésbé egyeduralkodó a világban. A klasszikus 


\section{TANULMÁNY}

Linz - Stepan (1996) szerzőpárost parafrazálva úgy is mondhatnánk: „democracy is no longer the only game in town". Így a liberalizáció, demokratizáció és konszolidáció sorrendjére épülő (Whitehead 2001), valamint elsősorban az intézményrendszerre fókuszáló tranzitológiai paradigma hamar válságba került (Csizmadia 2016). Formálisan persze továbbra is szinte minden politikus, párt, illetve rezsim a demokrácia megvalósítását és kiteljesítését tűzi zászlajára (Levitsky - Ziblatt 2018), azonban tartalmi szempontból komoly kétségek merülnek fel ezen szereplők valódi demokratikus elkötelezettségével szemben. Latin-Amerika, Afrika és Eurázsia (különösen a posztkommunista és posztszovjet térség) számtalan példát szolgáltat mind a mai napig megakadt vagy egyenesen fordított irányú demokratizációra (de-demokratizáció), illetve az autokratizálódás jelenségére (Cassani - Tomini 2018, Lührmann - Lindberg 2019). Ennek nyomán az évezredfordulót már a tranzitológiával történő leszámolás (Carothers 2002), valamint a hibridizáció (Diamond 2002) irodalmának felívelése jelezte.

Jól jelzi az azóta eltelt két évtized fejleményeit az a tény, hogy a teljes értékű demokráciák és a klasszikus diktatúrák közötti „szürke zóna” és „vegyes rendszerek” (Bunce - Wolchik 2011) fogalmi belakása eleinte jellemzően a „jelzős demokráciák" (Collier - Levitsky 1997) irányából indulva egyre inkább kiegészült a különféle „jelzős autokráciákkal” (Gerschewski - Schmotz 2011), létrehozva ezzel egy alig áttekinthető „terminológiai Bábelt” (Armony - Schamis 2005). Ezen megtorpant vagy felemás módon demokratizálódott, vagy egyenesen autokratizálódó rezsimek kapcsán olyan elterjedt politikatudományi fogalmak és elméletek születtek, mint például a delegatív demokrácia (O’Donnell 1994), az illiberális demokrácia (Zakaria 1997), a defektív demokrácia (Merkel 2004), vagy az irányított demokrácia (Wolin 2008). Az autokratikus jelleget az előbbieknél jobban kihangsúlyozzák a félautokrácia (Ottaway 2003), a liberális autokrácia (Zakaria 1997, Diamond 2003), a versengő autoriter rezsim (Levitsky - Way 2002, 2010) és a választási autokrácia (Schedler 2002, 2013) fogalmai. Ezen modellek kibontása és a hibrid irodalom sokoldalú áttekintése több kiváló magyar nyelvű tanulmány témáját is adta az elmúlt években (Böcskei - Szabó 2019, Körösényi - Gyulai 2019, Szűcs 2019, Kis 2019, Bozóki - Hegedûs 2017, Tóth 2016, Gyulai - Stein - Zalai 2016).

Az alapvető dilemma a hibrid irodalomban az, hogy vajon ezek a politikai berendezkedések egy önálló rezsimtípust testesítenek-e meg, vagy csupán a két fő kategória, a demokrácia és a diktatúra „csökkentett értékü” altípusairól van szó (Cassani 2014). A kérdés megválaszolása nagyban függ az egyes szerzők demokráciafelfogásától, és attól, hogy az ahhoz kapcsolt ellenfogalmak milyen természetű ellentétet fejeznek ki. Giovanni Sartori, klasszikus munkájában (1999) ennek illusztrálására megkülönbözteti a fokozatbeli különbségeket lehetővé tevő kontrárius ellentétet a kizárólagosságot jelentő kontradiktórius ellentéttől. Míg előbbiben lehetségesek köztes kategóriák (tertium datur), mint például a hideg-meleg vagy a szép-csúnya 


\section{TANULMÁNY}

ellentétpárok esetében, addig az utóbbinál nincsenek átmeneti kategóriák (tertium non datur), úgymint a házas vagy nem házas, vagy a kék vagy nem kék (kategoriális) ellentétpárok esetében. Sartori ennek megfelelően ki is jelöli a dichotóm felosztásban a demokrácia ellentétét az autokrácia (mint „nem-demokrácia”) fogalmával, méghozzá a hatalomba iktatás elve nyomán. Állítása szerint „az autokrácia autoinvesztitúra, azaz valaki vagy saját magát kiáltja ki vezetőnek, vagy örökletes jogon lesz az. Ezzel szemben a demokrácia elve szerint senki sem ruházhatja fel önmagát hatalommal. Mint látszik, a demokrácia és az autokrácia közti ellentét a hatalomba való beiktatás és a hatalom legitimációs elvében van. A beiktatásnak pedig nincsenek »fokozatai«: az egyes lehetőségek közt nincs átmenet. A demokrácia beiktatási elve ráadásul éppen fordítottja az autokrácia beiktatási elvének. A (helyszíni) bizonyítás pedig egyszerű: a választás jelenti a próbát. Minden rezsim, amelynek politikai »ellenőrző személyzetét « szabad, versengő és tiszta választások révén jelölik ki, a demokrácia kategóriájába tartozik. És ellenkezőleg, minden olyan rendszer, amelynek politikai ellenőrző személyzete nem választások útján került helyére, »nem demokráciának« minősül. Mivel a demokrácia elutasítja az autokratikus elvet, az lesz az alapelve, hogy az embernek csak az adhat más emberek feletti hatalmat, ha ezek a mások elismerik és hatalomba iktatják. Ezért ha a vezetők kinevezése nem népi konszenzus eredménye, nincs demokrácia. $S$ ha ezt a konszenzust meghamisítják vagy kikényszerítik, a demokrácia megszűnik létezni: nincs konszenzus, ha az egyetértést nem lehet megtagadni, s a konszenzus akkor is elveszti demokratikus értékét, ha nincsenek alternatívák, amelyek közt választani lehetne. (Sartori 1999: 109-110).

Sartori szerint az egyetértés és a népakarat meghamisításának elkerülése végett a szabad választások mellett a „véleménynek is szabadnak kell lennie, azaz szabadon kell formálódnia. A szabad választások kikényszerített (nem szabad) véleményekkel mit sem érnek. Egy olyan »szuverén « nép, amelynek nincs saját véleménye, üres szuverén. A demokrácia egész építménye végső soron a közvéleményre támaszkodik; arra a véleményre, amely valóban a köz véleménye". (Sartori 1999: 51). Arra, hogy a hatalom demokratikus jogcíme autokratikus hatalomgyakorlást leplezhet, Sartori szerint a „szó szerinti demokrácia elmélete” (amely szerint a demokrácia per se a nép uralma) nem tud válaszolni. Ugyanis a „demokrácia egész gépezetének gyenge pontját a hatalom transzmissziós szíjai alkotják, ezt pedig az etimológia optikája nem érzékeli. A választás és a képviselet valóban olyan eszközök, amelyek nélkül a demokrácia nem valósulhat meg; csakhogy éppen ezek jelentik Achilles-sarkát is: minthogy a választások nem szükségszerúen szabadok, s a képviselet sem szükségszerűen valódi." (Sartori 1999: 28) Ennek a helyzetnek az orvoslásához és megelőzéséhez Sartori a demokrácia leíró és előíró értelmezéséhez nyúl, amely középpontjában a korlátozott hatalom koncepciója áll. Sartori ugyanis nem csupán negatív meghatározással él a demokrácia kapcsán (ti. nem-autokrácia), hanem pozitív leíró (választott poliarchia) és előíró (szelektiv poliarchia, azaz választott meritokrácia) 


\section{TANULMÁNY}

definíciókkal is. Így a demokrácia egy olyan rendszer, amelyben senki sem választhatja meg és iktathatja hatalomba önmagát, azaz nem követelhet magának feltétlen és korlátlan hatalmat. A demokráciában „a »minden hatalmat a népnek« elvnek lassan a »senkinek sem minden hatalmat « elvvé kell alakulnia”, amely „olyan hatalomgyakorláshoz vezet, amelyben a nép hatalma a hatalmon lévők ellenőrzésében és leváltásában fejeződik ki” (Sartori 1999: 49). Ez pedig abban a liberális-demokratikus államban valósulhat meg, amely a demokrácia „egyetlen teljes elméletére”, azaz a liberális demokráciára épít (Sartori 1999: 18). Habár a dichotóm felosztástól függetlenül lehetséges az egyes kategóriákon belüli fokozatokról beszélni, a kontradiktórius határhúzás mozzanata a demokrácia fogalmának használhatóságát (rögzítettségét) célozza, éppen az olyan határviták kiküszöbölésével, amelyek a nem kizáró jellegü ellentétpárok kapcsán óhatatlanul előkerülnek.

Az ellentétpárok természetének kérdése a hibrid irodalomban elsősorban a duális, illetve hármas megközelítésekben jelentkezik. Jól illusztrálja a különbséget a kutatási terület két, leginkább használatos fogalma, a versengő autoriter rezsim (Levitsky - Way 2002, 2010) és a választási autokrácia (Schedler 2002, 2013). Előbbi esetben a demokrácia - hibrid rezsim - diktatúra hármas felosztása a tertium datur átmenetiségét példázza, amelyben a középső kategóriában egyszerre léteznek demokratikus és autokratikus elemek. A szerzők szerint a köztes zóna hibrid politikai rendszereit központilag szervezett vagy tolerált normasértés(ek) jellemzik a szabad választások, a polgári szabadságjogok széleskörű védelme és az egyenlő játéktér kritériumaival szemben. Utóbbi kapcsán elsődlegesen a forrásokhoz, a médiához és a nyilvánossághoz, valamint a korrekt jogalkalmazáshoz való hozzáférés lehetőségeiben torzított szisztematikus módon a politikai verseny. Ezek a rezsimek olyan berendezkedések, „amelyekben formálisan léteznek demokratikus intézmények, és a politikai küzdelem is elsődlegesen ezekben zajlik, de a hatalmon lévők az államot arra használják, hogy lényeges erőfölényhez jussanak ellenfeleikkel szemben. Ezek a rezsimek annyiban kompetitívek, hogy az ellenzéki pártok a demokratikus intézményeken keresztül próbálnak versengeni a hatalomért, annyiban viszont nem demokratikusak, hogy a játéktér a hatalmon lévők javára lejt. A versengés valódi, de nem tisztességes." (Levitsky - Way 2010: 5)

Ezzel szemben a Schedleri rendszer-tipológia alapvetően a demokrácia (liberális demokrácia és választási demokrácia) és az autokrácia (zárt autokrácia és választási autokrácia) dichotómiájában gondolkodik, amely a Sartori-féle tertium non datur ellentéttípusának feleltethető meg, és amelyben a választási demokrácia és a választási autokrácia között húzódik a fő határvonal. Fontos, hogy Schedler rámutat arra, hogy ha a demokratikus defektusok eltörlik egy választási rezsim demokratikus jellegét, akkor érdemes nevén nevezni azt, amit látunk, azaz az autokráciát. Ha ugyanis nem-demokratikus rezsimeket demokráciaként értelmezünk, akkor abba a módszertani hibába esünk, amelyet Sartori (1984) „fogalmi nyújtásnak” (conceptual stretching) nevezett. Schedler számára tehát a „rendszermeghatározó 


\section{TANULMÁNY}

elem nem a választás megléte - mint a Levitsky-Way-féle versengő autoriter hibrid rendszernél -, hanem a verseny valódisága" (Unger 2018: 9). Ezt azonban nem a demokratikus választások, hanem a választási autokráciák belső működésmódja és manipulációs technikái felől vizsgálja. Értelmezésében ezekben a rezsimekben ugyan többpárti választásokat tartanak, azonban ezen választások „demokratikus szellemét súlyos és rendszerszerű manipulációval fojtják meg” (Schedler 2013: 55). Jelentős különbség tehát Schedler és a Levitsky - Way szerzőpáros fogalmai között, hogy Schedler dichotóm megközelítése során saját modelljét világosan az autokráciák közé sorolja. Ráadásul, míg a Levitsky-Way-féle megközelítésben a választásokra többpárti jellege miatt versengőként és így egy kevert (hibrid) rezsim demokratikus elemeként tekintenek, addig Schedler szerint ezek a manipulált többpárti választások nem a politikai versenyt - és így a demokratikus jelleget - biztosítják, hanem a látszatfelhatalmazást a látszatdemokrácia homlokzatán. Így a formális „képviseleti intézmények bájos dekorációk az autoriter rendszerek kirakatában" (Schedler 2013: 69).

\section{A klónok támadása}

Állításom szerint az eddigiekben röviden áttekintett globális demokráciakrízis és az új típusú autokráciák elterjedése szorosan összefüggenek az elmúlt évtizedek egyik legkutatottabb politikatudományi témájává váló populizmus térhódításával. Olyanynyira, hogy véleményem szerint a populizmus lehet az a kapocs, amelyik nem csupán leírja, és megfelelő elméleti keretbe ágyazza, hanem sok tekintetben magyarázza is a globális demokráciakrízist és a posztmodern autokráciák múködését. Az állítás érvényessége persze nagyban függ attól, hogy mit értünk populizmus és demokrácia kifejezések alatt, illetve azzal, hogy miképpen viszonyulunk a liberális demokráciák többségellenes intézményeihez, amelyek a máskülönben korlátlan népszuverenitás potenciálisan pusztító hatású következményeit hivatottak kordában tartani. Éppen ezért vizsgáltam meg korábban a populizmus és a képviseleti demokrácia viszonyának megítélését a mainstream populizmus-irodalomban (Benedek 2019), amely során három fő megközelítést különböztettem meg. Az első (a populizmus mint „lehetőség”) a populizmust a Carl Schmitt által kidolgozott politikai fogalmával megfeleltetve a demokrácia és a politika szükségszerű és kívánatos populista fordulatát hirdeti, abban mindenekelőtt egy emancipatorikus és radikális, a konfliktusokat se nem totalizáló, se nem kiiktatni akaró demokrácia lehetőségét látja (Laclau 2011, Mouffe 2018, Antal 2017). Ugyanakkor abból a szempontból nem ideális ez a megközelítés, hogy így minden politikai aktor végső soron többé vagy kevésbé, de egyúttal populista is, amely magát a terminológiát teszi redundánssá és feleslegessé. Ha ugyanis egy fogalom mindent megpróbál magyarázni, akkor nem magyaráz meg semmit sem. 


\section{TANULMÁNY}

A második és egyúttal a populizmus-kutatásban uralkodó szemlélet a demokráciát egyfelől minimalista módon definiálja, másfelől azt jellemzően egy demokratikus (populista) és egy liberális-alkotmányos pillér „paradox feszültségében” interpretálja. Ebben az értelemben a populizmus egy olyan „vékony középpontú” ideológia, „amely úgy véli, hogy a társadalom végeredményben két homogén és egymáshoz antagonisztikusan viszonyuló csoportra oszlik, a »tiszta emberek« és a »korrupt elit« csoportjaira, és amely szerint a politikának az emberek általános akaratát kellene tükröznie" (Mudde 2004: 562). Eszerint a demokrácia liberális-alkotmányos pillérének túlsúlyba kerülése nyomán a populizmus mint korszellem, a modern demokratikus képviseleti politika egyre súlyosabb működésbeli zavarainak önmagában el nem ítélhető jelzése (Mény - Surel 2002, Mudde 2004, Mudde - Rovira Kaltwasser 2013, Judis 2016). Azonban ebben a megközelítésben szinte reflektálatlan marad a populizmus éles antipluralizmusa és politikai kizárása, amely így egy demagógiaszerű fogalom marad, amely továbbra is túl széles ahhoz, hogy érdemben használni lehessen. Végső soron nehéz megmondani, hogy pontosan kik is a populisták és kik nem, hiszen manapság gyakrabban vagy ritkábban, de szinte minden politikus a nép nevében beszél és hangosan kritizál bizonyos elitcsoportokat és politikai ellenfeleket. Így ez a fajta populizmus-koncepció leginkább egyfajta határvonalat jelöl a hagyományos mérsékelt pártok és a többé vagy kevésbé harsány, feltörekvő újabb kihívóik között. Ezzel a populizmus fogalma egy sajátos, kissé homályos eszközzé vált, amely segítségével elhatárolják egymástól az olyan politikusokat, mint Angela Merkel, Sebastian Kurz és Joe Biden az olyanoktól, mint Matteo Salvini, Orbán Viktor és Donald Trump, amely megnöveli annak a lehetőségét, hogy a populizmus kifejezés használóit ideológiai elfogultsággal vádolhassák. Ráadásul számtalan „borderline” politikus van, akik a különféle vizsgálatokban hol bekerülnek, hol kikerülnek a populisták csoportjából, mint például Bernie Sanders, Emmanuel Macron vagy Jeremy Corbyn. Végezetül egyre gyakrabban tűnik úgy, hogy mára a kihívók, azaz a populisták csoportja adja a többséget, ezzel jelentősen elinflálódik a fogalom értéke is.

A fenti okok nyomán a populizmus-kutatás harmadik, a populizmust a legszükebb és legszigorúbb értelemben használó megközelítését követem, amely a populizmust egyértelműen veszélyként értelmezi a demokrácia számára. A demokráciát ennek megfelelően robosztusabban definiálom, amelybe immanensen beleértődik a liberális-alkotmányos pillér (Abts - Rummens 2007, Müller 2016, Urbinati 2013). Ebből a perspektívából a populizmus egy, a demokratikus működészavarok nyomán felfutó „rossz társadalmi közérzetet” manipulatív módon kihasználó veszélyforrás, egészen pontosan egy olyan trójai faló, amely segítségével az új politikai szereplők képesek gyorsan hatalomra szert tenni anélkül, hogy a népszerűség növekedéséhez hosszú választási ciklusokat kellene várniuk. A demokrácia fogalma kapcsán pedig Sartori már említett definícióit alkalmazom, miszerint a demokrácia választásos és szelektív poliarchia, amelynek középpontjában a népszuverenitás és a hatalom korlátozása áll. Ezt kiegészítem a francia filozófus, Claude Lefort megközelítésével, 


\section{TANULMÁNY}

aki szerint a demokrácia egy olyan rendszer, ahol a hatalom helye (locus) egy üres pozíció (Lefort 1988: 17-19, 224-235). Lefort szerint míg a premodern időkben a hatalom helye a királyban öltött testet, addig a modern demokráciákban a politikai hatalommal járó hivatalok ideiglenes jellegűek és rendszeres politikai és választási versengésnek vannak kitéve. A politikai közösség egysége már nem egy homogén nép organikus egységére utal, hanem a politika színpadának egységére, azaz a pluralizmus olyan közös politikai színhelyére, ahol a visszafordíthatatlanul diverz társadalom konfliktusainak és feszültségeinek politikaivá transzformált és szelídített küzdelmei vívódnak meg. Éppen ezért, a politikai közösség identitása és a népakarat „sosem nyerhet el egy végső értelmezést, és az ehhez kapcsolódó demokratikus folyama sosem zárulhat le" (Abts - Rummens 2007: 413). Lefort szerint ez az állapot mind az önmagában való diverzitás, mind pedig az önmagában való egység irányába is torzulhat. Előbbi esetében a hatalom megszűnik kézzelfoghatóvá lenni, és különféle preferenciák és érdekek összeegyeztetésének lesz a lecsupaszított eszköze. Ekkor, a liberális logika nyomán a hatalom üres helye eltünhet, köszönhetően a személytelen intézményi működésnek, ahol nincs utalás a közjóra vagy a demokrácia eszméjére, mint közös projektre, amely politikai dezintegrációhoz vezethet. Ez pedig utat nyithat az ellentétes logikával operáló populizmusnak, amelyben a nép és annak képviselete egységként tételeződik, és amely nem ismer el semmilyen legitim különbözőséget, ezzel tagadva a társadalmi sokszínűséget. A populista logikával tehát a hatalom üres helye bezáródhat egy homogén nép imágójával, megszüntetve ezzel a demokráciához szükséges dinamikát a legitim identitások terén. Következésképp, a populizmus immanens antipluralizmusa nem teszi lehetővé, hogy demokratikus minőséggel ruházzuk fel.

A tanulmány második részében igyekszem demonstrálni egyfelől, hogy a demokrácia és a képviselet egy autokratikus értelmezéseként felfogott populizmus, mint egy trójai faló, különösen nagy veszélyt jelent a demokráciákra, mindenekelőtt a homogénnek képzelt nép egységes akaratának és a közjó meghatározásának kisajátítására törekvő, megcáfolhatatlan morális képviseleti igénye miatt. Másfelől amellett érvelek, hogy a populizmus a posztmodern autokráciák múködésében is kulcsfontosságú lehet, hiszen az ilyen, formálisan ugyan többpárti választásokkal operáló rezsimek számára a politikai versengés szisztematikusan eltorzított, így csupán korlátozott jellegét, valamint a rendszeren belüli újabb és újabb autokratikus tendenciák elfedését és legitimálását szolgálhatja.

\section{A POPULIZMUS MINT AZ ANTIDEMOKRATÁK TRÓJAI FALOVA}

Elsőként szeretném alaposabban megvilágítani azt az állítást, miszerint a populizmus a demokrácia és a képviselet egy autokratikus értelmezése. Ahogyan már jeleztem, a populizmus mindenekelőtt a politika egy olyan morális megközelítése, amely- 


\section{TANULMÁNY}

ben a politika világa egy morálisan tiszta és egységes nép, és a vele szemben álló, korrupt vagy más módon alsóbbrendűnek tartott elit csoportjára oszlik. Ebben az értelemben az elitkritika szükséges, de önmagában elégtelen feltétele annak, hogy valakit populistának tartsunk, hiszen az utóbbiak nem csupán antielitisták, hanem antipluralisták is, azt állítva, hogy „ők, és csakis ők képviselik igaz módon a népet”. Véleményem szerint a populizmus megítélésében ez a fajta politikai kizárás a kulcs. A populisták esetében „minden más politikai versenytárs az erkölcstelen és korrupt elit része egészen addig, amíg hatalomra nem kerülnek, ott pedig nem ismernek el semmilyen ellenzéket legitimnek" (Müller 2016: 20). Ezért, a populisták már nem hétköznapi ellenfelekként tekintenek a riválisokra, hanem olyan politikai ellenségekként, amely összeegyeztethetetlen a hatalom üres helyére vonatkozó Lefort-i szimbolikus struktúrával. Ezzel a megközelítéssel a populisták a társadalom és annak képviseletére szerződött politikai erők jelentős részét kizárják a nép fogalmából, miközben más részüket az egésszé nyilvánítják egy sajátos, pars pro toto logika nyomán. A populisták a szélsőségesen polarizáló morális határhúzással az ellenfeleiket bármi áron legyőzendő ellenséggé, a bizonyos mértékű közösségvállalást és konszenzust feltételező, a mindenkori vesztesek számára is védelmet biztosító demokratikus politikai küzdelmet pedig bizonytalan kimenetelü élet-halál harccá változtatják. Ezt jól illusztrálja az a tény, hogy a populisták a morális antipluralizmusukból következően gyakorta tagadják a választások eredményeit, különösen akkor, ha a számok nem igazolják rendkívüli és karizmatikus politikai szerepüket. Elegendő ennek kapcsán Donald Trump beszédére gondolni a 2020-as elnökválasztás másnapján, amellyel az egész választási rendszer legitimációját kérdőjelezte meg a vereség elismerése helyett, vagy Orbán Viktornak az elveszített 2002-es országgyűlési választásokat követő üzenetére, miszerint a „haza nem lehet ellenzékben”. Kudarc esetén tehát a probléma sosem a populisták képviseleti alkalmatlanságában rejlik, hanem „mindig az intézményekben, amelyek valahogyan rossz végeredményt mutatnak" (Müller 2016: 32).

Ez a fajta antipluralizmus és intézményellenesség Carl Schmitt liberalizmus- és parlamentarizmus-kritikájából (1988) is kibontható. Schmitt elvetette a 20. század tömegdemokráciáit, mondván, hogy azok csupán a részérdekeket kiszolgáló puszta homlokzatok, és a választási elszámoltathatóságuk a piaci, semmint a valódi politikai folyamatokra hasonlít. Ezzel szemben, a nép a valódi szuverén, amelyet nem lehet formális eljárásokkal és intézmények által képviselni, mert ezzel megszűnne a szuverenitása, helyette egy közvetítés nélküli identitás szükséges a vezető és tárgya között, amelyben előbbi közvetlenül testesítheti meg az általános népakaratot. Így a nép hozzájárulása a hatalom legitimálásához Schmitt szerint azonosulással és akklamációval történhet, hiszen „ez az egyetlen érvényes elszámoltathatóság, mivel ez az egyetlen valóban politikai mód, nem a procedurális és formális, nem a közvetített, hanem a követlen” (Schmitt, idézi Urbinati 2019: 122). Schmitt szerint a „magánemberek százmillióinak egyhangú véleménye nem jelenti sem a nép akaratát, 


\section{TANULMÁNY}

sem a közvéleményt. A nép akarata közfelkiáltással, akklamációval, magától értetődő, vitathatatlanként elfogadott létezéssel éppen olyan jól és még demokratikusabban nyilvánítható ki, mint azzal a statisztikai apparátussal, amelyet fél évszázada oly aprólékos gondossággal alakítottak ki. Minél erősebb a demokratikus érzés, annál bizonyosabb a felismerés, hogy a demokrácia valami más, mint titkos szavazások regisztrációs rendszere. A nem csupán technikai, hanem vitális értelemben közvetlen demokrácia színe előtt a liberális gondolatmenetekből létrejött parlament mesterséges gépezetként jelenik meg, miközben a diktatórikus és cezarisztikus módszereket nem csak a nép akklamációja hordozhatja, hanem lehetnek a demokratikus szubsztancia és erő közvetlen megnyilatkozásai" (Schmitt 1988: 16-17). Ebben az esetben a vezető legitimációja kizárólag azon alapszik, hogy részt vesz a politikai közösség egységes és homogén identitásában, így közvetlenül adhat hangot a nép akaratának. Ezzel szemben a parlamentarizmus - amely az általános népakarat közvetlen kifejeződését helyettesíti - aláássa a szuverenitást, hiszen az nem alkotható vagy fedezhető fel deliberatív folyamatok során, helyette a vezér népi felavatásában és közfelkiáltásban manifesztálódik (Abts - Rummens 2007: 415-416.). Ezért ez a fajta képviselet (represent) inkább megtestesítés (presentation vagy embodiment), semmint demokratikus képviselet. Az egyik központi állításom éppen ezért az, hogy az akklamáció nem tartozik Sartori-féle demokratikus beiktatás (szabad, versengő és tiszta választások) kategóriájához, hanem az autokráciák egy speciális autoinvesztitúra által jellemezhető válfajához tartozik, amelyben valaki saját magát kiáltja ki vezetőnek és a népakarat egyetlen legitim megtestesítőjének, miközben minden más politikai riválistól megtagadja a politikai közösség legitim képviseletének jogát. Amikor egy populista vezér magát a népakarat egyetlen legitim képviselőjének nyilvánítja, akár mindenféle választási mandátumtól függetlenül is, akkor „nem csupán az állami intézmények korrupt és rossz múködését hirdeti, hanem az egész választásokra épülő politikát is, annak képviseleti jellegét is" (Urbinati 2013: 153).

Ennek a politikai logikának a használatával és az extrém politikai polarizáció különféle formáival a populisták antagonisztikus törésvonalakat metszenek a társadalomba. Ezzel végletekig fokozzák a demokráciákban kezelhető mértékben egészséges és nélkülözhetetlen állampolgári bizalmatlanságot (Rosanvallon 2008), aláásva a demokráciához szükséges kölcsönös tolerancia és intézményes önmérséklet „puha védőkorlátait" (Levitsky - Ziblatt 2018). Márpedig védőkorlátok és egymás minimális kölcsönös tisztelete nélkül nem beszélhetünk a demokráciákhoz szükséges közös politikai színpadról sem. Amennyiben a „politika eredendően egy közös színpad létét és az azon megjelenők létét és státusát érintő konfliktus" (Rancière 1999: 26-27), akkor a demokrácia egy olyan speciális színpadnak tekinthető, amelyben a pluralitás elfogadása - mint az egyének diverzitása, mint különféle legitim politikai aktorok küzdelme, valamint a hatalom megosztottsága - kulcsfontosságú. A demokrácia tehát egy olyan rendszer, amelyben a politika pluralista felfogása alapvető, és ahol a hatalom korlátozott és senkihez sem tartozik kizárólag, így egy üres hely 


\section{TANULMÁNY}

marad. Valóban, akik a demokráciákban a hatalmat gyakorolják, azok nem birtokolják azt, a gyakorlása ugyanis „rendszeres versengésnek van kitéve, a hatalommal felruházottak tekintélye pedig a nép akaratának megnyilvánulása eredményeként jön létre újra és újra. A hatalom üres helye egy olyan társadalomra utal, amely nem rendelkezik egy olyan pozitív meghatározással, amelyet a közösség figurája képviselhetne" (Lefort 1988: 225-226). Ezzel szemben a populizmus egy végső és tartalmilag meghatározott népakarat értelmezéssel és a politikai közösség organikus egységének képzetéhez kapcsolódó identitással megpróbálja végérvényesen lezárni az ezekhez kapcsolódó, eredendően vég nélküli demokratikus folyamatokat. Pontosan ez a fajta, a hatalom és a nép legitim identitásának üres helyét bezárni akaró logika jelenti a populizmus lényegét, amely ezért a demokrácia és a képviselet egy autokratikus értelmezése, nem pedig a demokrácia egyik pillére, ahogyan azt a fósodratú populizmus-kutatás állítja.

Egy választás ahhoz, hogy demokratikus legyen, teret kell, hogy engedjen a nézetkülönbségeknek is. Éppen ez az, amiért a demokrácia a többség elvét, nem pedig az egység elvét implikálja. Ugyanakkor a populista akklamáció „nem engedélyezi, vagy nem értékeli a disszenzus kifejezését”, mivel „a populista gyülekezésnek nem szükséges megszámolnia a szavazatokat vagy elismernie a kisebbségeket, mivel a vezér az egésznek a vezetője lesz, nem csupán a többségé” (Urbinati 1998: 119). A vezér attól „karizmatikus”, hogy „rendkívüli ajándékkal” van felruházva: felismeri a közjót úgy, ahogyan az emberek látják (Müller 2016: 33.). Képviseleti logikája ellehetetleníti a demokráciához nélkülözhetetlen elszámoltatást, hiszen az egyértelmű, ilyen értelemben kötött mandátum (népakarat), ahogyan az azt egyértelműsítő válság (mint kivételes állapot) is kizárólag a vezér (mint a szuverén) interpretálásától függ. Mivel pedig a népakarat és a közjó saját hatáskörben történő meghatározásáról van szó, ezért valójában nincs a démosz irányából valódi mandátum, amelyet el lehetne számoltatni. Így a plebiszciter ruhába bújt és a politikai képviselet végletesen aszimmetrikus formáját megvalósító populizmus nem tekinthető demokratikusnak, és a „választás” csupán üres rituálévá válik. Ebben a logikában a populista vezér a politikai folyamatok alfája és omegája, míg az állampolgárok tömegei arra vannak kárhoztatva, hogy a vezér előadásának passzív közönségei legyenek, akik csupán a vezér által megfogalmazott népakaratra reflektálva adhatnak egy biankó-csekk jellegű szabad felhatalmazást az organikus vezetőnek. A populisták állítása végső soron tautologikus, hiszen azt mondják, „hogyha nem értesz egyet a népakarattal, ahogy én interpretálom, és nem ismersz el engem az ezt megfogalmazni képes egyetlen vezetőnek, akkor nem is tartozol a (valódi) néphez". Azaz a valódi nép attól autentikus, mert az egyetlen legitim vezért ismeri el, aki attól legitim, mert a nép őt ismeri el. Márpedig „ahogy a választók nélküli képviselet kétséges, ugyanúgy a választás sem lesz több, mint a hatalom gyakorlásáról való periodikus lemondás, ha nincsenek bizonyos garanciák, ha nem biztosítják a szabadságához szükséges feltételeket. Ha a »vélelmezett« képviselet misztifikáció, a »választék nélküli« választás 


\section{TANULMÁNY}

csalás” (Sartori 1999: 27). Azaz „hacsak valaki nem akar lemondani a demokrácia azon fogalmáról, amely magába foglalja a hatalomkorlátozást, az alkotmányos civilés politikai szabadságjogokat, valamint a nyilvános vitát, mint a politikai élet sajátos formáját, akkor arra kényszerül konkludálni, hogy a populizmus nem a demokrácia kifejeződése" (Urbinati 1998: 122).

Azonban ahogyan Lefort kapcsán jeleztem, a demokráciákban a hatalom üres helye nem csupán a populizmussal torzulhat, ahol az bezáródik egy tartalmilag is determinált homogén nép imágójával, hanem a liberális logika mentén is, amelyben a hatalom helye eltűnhet a látóhatárról. „Az önmagában való diverzitás liberális illúziója a hatalmat instrumentalizálja, a népakaratot fikcióként redukálja, és kizárólag egyének és érdekcsoportok véleményét ismeri el valódinak, amely így a társadalom lényegét tagadja” (Lefort 1988: 232-233). Ez a fajta „túlintézményesülés”, amelyben a hatalom a teljesen személytelenné váló eljárásokban és jogállamban oldódik fel, a demokrácia egy ellenkező típusú eltorzulásaként értelmezhető, amely tulajdonképpen csupán lecseréli a populista egységes nép személetét egy másfajta, szintén nem demokratikus elképzelésre. Ebben az értelemben Cas Mudde és Rovira Kaltwasser jól látja, hogy „egy olyan világban, amelyben a demokrácia és a liberalizmus uralkodik, a populizmus alapvetően az antidemokratikus liberalizmusra adott demokratikus illiberalizmus válaszává vált” (Mudde - Rovira Kaltwasser 2017: 116), bár hozzá kell tenni, hogy pontosabb lenne a „kvázi-demokratikus válasz” kifejezés.

Ahogyan láthattuk, a globális demokráciakrízis egyik központi eleme éppen ez a fajta liberális depolitizáció, amely egyúttal a populizmusnak is utat nyitott. A populista vezetők erőteljesen támadják a liberális demokráciákat és tovább mélyítik azok legitimációs válságát a különféle intézményellenes üzenetekkel, az extrém mértékű polarizációval és a demokráciába vetett állampolgári bizalom aláásásával. Azt ígérik, hogy kiteljesítik a demokráciát és visszaadják a kontrollt a népnek (a „csendes többségnek"), így mindig egyfajta demokrácia-létrehozó vagy újjáélesztő retorikával és mítosszal operálnak. Az antagonisztikus konfliktusok gerjesztésével és polarizáló politizálással egyszerre képesek az állampolgárokat depolitizálni és passzivitásra kárhoztatni, valamint a politika iránti általános neheztelésüket erősíteni azáltal, hogy növelik a negatív percepciókat és attitűdöket a demokrácia mindennapi működésével kapcsolatban, ugyanakkor egy jobb élet reményében a tömegek repolitizálására és aktivizálására is alkalmasak lehetnek. Ezért a populizmus egyszerre idézi elő és testesíti meg a globális demokráciakrízist, azaz egyszerre következménye és oka az utóbbinak. A populizmus kapcsán a veszély tehát a demokrácia kiteljesítésének ígéretével és látszatnyelvezetén érkezik. Következésképpen a populizmus egy trójai faló az olyan valódi antidemokraták számára, akik a formálisan a nép nevében, ugyanakkor tartalmilag a nép nélkül szeretnék a hatalmat gyakorolni. Ebben az esetben be kell, hogy lássuk, hogy viszonylag kevés - például Bernie Sanders vagy Sebastian Kurz nem tartozik ide, hiszen ők az időnként harsány antielitizmusuk ellenére sem állítják azt, hogy „ők, és csak ők képviselik legitim módon a népet”, ellentétben 


\section{TANULMÁNY}

Donald Trumppal vagy Orbán Viktorral -, de a demokráciára nézve annál veszélyesebb populista létezik manapság.

\section{A POPULIZMUS MINT A POSZTMODERN AUTOKRÁCIÁK FÜGEFALEVELE}

A tanulmány záró szakaszában amellett érvelek, hogy a populizmus nem csupán a globális demokráciakrízis, hanem az új típusú autokráciák számtalan aspektusának leírására és megfelelő elméleti keretbe helyezésére, illetve a mindennapi múködésük magyarázatára is alkalmasnak tűnik. Véleményem szerint elsősorban azért, mivel a posztmodern autokráciák szisztematikusan eltorzított, így korlátozottan versengő jellegét, valamint a rendszeren belüli újabb és újabb autokratikus tendenciákat elfedheti és legitimálhatja. Röviden, a hatalomgyakorlás autokratikus természetét fügefalevél módjára képes eltakarni. Ugyanis ahogyan korábban már láthattuk, a demokrácia autokratikus átértelmezése során a populizmus nem csupán abszolutizálja a népakaratot, hanem annak tartalmi meghatározását is kizárólagosan a populista vezér számára sajátítja ki, ezzel pedig minden egyéb rivális politikai szereplőt delegitimál, végső soron kitagadja őket a démosz legitim tagjai közül. Ekkor a populista vezér „minden hatalmat nekünk” csatakiáltása nem alakul át azzá, hogy „senkinek sem szabad minden hatalmat birtokolnia”, ezzel pedig a demokráciától idegen abszolút hatalomra tör, amellyel a „betű árulja el a szellemet” (Sartori 1999: 49). Fontos tehát látni a populizmus kapcsán, hogy nem csupán egy harsány elitkritikával jelentkező egységes népfelfogásról és a népakarat korlátlan érvényesülésének igényéről van szó, hanem egy olyan kognitív szoftverről, amely folyamatosan antagonisztikus törésvonalakat alakít ki. Azaz, különösen érdekellentétek esetén, valaki vagy a vezérrel van (in-group), vagy a minden áron és módon legyőzendő, és ezért rendszeresen explicit módon is alsóbbrendűnek tartott ellenség táborához (outgroup) tartozik. Ebből következik, hogy ha a populizmus manicheista világképében a népakarat egyetlen legitim megtestesítőjeként munkálkodó populista vezér legitim ellenfelei illegitim ellenségekké válnak, akkor a démoszra és a közjóra történő hivatkozás kvázi-demokratikus nyelvezete mellett is igazolást nyerhetnek a velük történő leszámolást célzó legsúlyosabb autokratikus lépések is. Ezért a populizmus politika- és demokráciaképe kifejezetten kompatibilis az autokraták hatalmi szándékaival.

A modern autokráciákkal szemben, amelyek elsősorban transzcendens, örökletes, teljesítményelvű vagy ellentmondást nem tűrő ideológiai alapon tartanak igényt a hatalomra, a posztmodern autokráciák egyebek mellett számottevő mértékű kvázi-demokratikus legitimációt is használnak a nép nevében történő hatalomgyakorlás során. Ezért az autokratikus uralmat általános választójogra épülő többpárti választások mellett gyakorolják. Azért, hogy minimalizálják vagy teljesen kiiktassák a versengés kockázatait, egyrészt szisztematikusan korlátozzák és a maguk javára 


\section{TANULMÁNY}

torzítják a versenyfeltételeket, másfelől gyakran élnek a számukra hasznos populista demokrácia- és képviselet-felfogással. Következésképpen, az autokratikus eszköztárat (hardware) gyakran kiegészítik egy kvázi-demokratikus szoftverrel, amely igazolhatja a morális és politikai egyenlőtlenségeket. Ez a kapcsolat az autokrácia szerkezetének, valamint a manipulatív és top-down módon legyártott és önkényesen meghatározott népakarat abszolutizálására épülő, a népakarat meghatározásának jogát kizárólagosan magának vindikáló, ennek nyomán másokat a politika terrénumából rutinjelleggel kizáró és delegitimáló populizmus házasságaként írható le. Ezáltal a populista autokráciák a posztmodern autokráciák egy paradigmatikus típusát adják, létrehozva egy sajátos, populista autokráciát kiteljesítő szimbiózist, amelyben a trükkös autoinvesztitúra a populizmus nyelvezetével és politikai következményeivel van elrejtve. Az autokratikus kormányzás a populizmus felhasználása révén a számára oly fontos demokratikus látszat-legitimitáshoz és a sok esetben explicite is autokratikusnak deklarált, önkényes hatalomgyakorlás igazolásához jut hozzá, míg az autokratikus eszköztár nyomán a populizmus irányába a polarizáló hatású ellenségkép-gyártási mechanizmusok jutnak szüntelenül jelentős forrásokhoz és támogatáshoz.

Ezzel a megközelítéssel közelebb léphetünk a posztmodern autokráciák stabilitásának és legitimációs mechanizmusainak komplexebb értelmezéséhez is, amely a kurrens politikatudomány egyik kitüntetett programja (Gerschewski 2018, 2013, Dukalskis - Gerschewski 2017, Mazepus 2017). Véleményem szerint ez a fajta komplex megközelítésmód kifejezetten nélkülözhetetlen a posztmodern autokráciák alkalmazkodóképessége és flexibilitása kapcsán, amelyek a legfőbb okai a sok esetben meghökkentő mértékű ellenálló képességnek (resilience). Az autokratikus rezsimek stabilitása a represszió, a kooptálás és a legitimáció egymást kölcsönösen erősítő és kiegészítő pillérein nyugszik (Schedler 2013, Gerschewski 2013). Ezeken keresztül képesek az autokratikus rezsimek elkerülni az összeomlás veszélyét, amely az állampolgárok fellázadásának, az ellenzéki aktorok szervezett ellenállásának és az eliten belüli megosztottság irányaiból érkezhetnek (Morgenbesser 2017). A represszió az „autokráciák gerince” (Gerschewski 2013: 21), amely funkciója, hogy „eltántorítsa a politikai elitet a hűtlenség választásától, illetve megnehezítse az állampolgárok kollektív cselekvésének megszerveződését” (Morgenbesser 2017: 208), míg a formális és informális kooptálás funkciója, hogy a fóbb politikai aktorokat „meg lehessen győzni arról, hogy hatalmukat ne használják obstrukcióra” (Shleifer - Treisman 2000: 8-9.). Azonban mivel „hosszabb távon egyetlen politikai rezsim sem építheti fennmaradását kizárólag a represszióra és a kooptálás intézményére" (Bartha - Kopasz 2019: 106), ezért az autokráciák számára is fontos, hogy rendelkezzenek legitimációval (Gerschewski 2018, Dukalskis - Gerschewski 2017, von Haldenwang 2017, von Soest - Grauvogel 2017, Debre - Morgenbesser 2017, Cassani 2017, Backes Kailitz 2015), amely a posztmodern autokráciák esetében elsősorban kvázi-demokratikus legitimációt jelent. Ezzel különösen hatékonyan képesek az autokratikus 


\section{TANULMÁNY}

uralmat kevésbé költségessé tenni és a megfelelő állampolgári hozzáállást kiváltani az aktív egyetértéstől a passzív belenyugváson át a puszta toleranciáig, amelyben a populizmusnak kitüntetett szerep jut, hiszen elmélyíti a rezsim számára kedvező politikai-társadalmi törésvonalakat, elvégezve ezzel a stabilitáshoz szükséges mobilizálációs és demobilizációs feladatokat. A választások segítségével a posztmodern autokráciák a saját legitimációjukat erősítik meg, hiszen olyan morális igazolást nyer a hatalomhoz való joguk, amelyet máskülönben elérhetetlen lenne számukra.

A populizmus a posztmodern autokráciák stabilizációs rendszerének minden dimenziójában kiemelt szerepet tölthet be, megteremtve ezzel a populista autokráciát. A represszió egy sajátos formájaként a populizmus a rezsim minden potenciális ellenfelét delegitimálja és politikailag kizárja, hatékonyan korlátozva ezzel a politikai alternatívák létezését és esetleges hatásait. Ebben az értelemben a populizmus egyfajta kognitív erőszaknak és elnyomásnak tekinthető, amely a másként való gondolkodást korlátozza, félelmet keltve a népből való morális kirekesztéssel és annak ellenségeként való kezeléssel. Ugyanígy, a populizmus egy kooptálási mechanizmus is lehet, hiszen a kooptált politikai aktorokat nem okvetlenül a kizárástól való félelem, hanem az azzal járó anyagi, vagy más jellegű károk is motiválhatják egy költség-haszon kalkuláció végén. Végezetül, a populizmus többféle módon járulhat hozzá egy autokratikus rezsim legitimációjához is. Elsősorban azzal, hogy segítségével az autokratikus vezető a nép nevében beszélve egy kvázi-demokratikus nyelvezetet használhat, eljátszva egy demokratikusan megválasztott és legitimált vezető szerepét. Ezen felül a populista autokráciák a vezér által artikulált népakaratra hivatkozva képesek elrejteni és igazolni a hatalomgyakorlás autokratikus természetét, a szisztematikusan eltorzított versenyfeltételeket és az ellenzék morális alsóbbrendűségét. Továbbá a népakarat kizárólagos és morálisan cáfolhatatlan képviseleti igényével a populizmus az egész jogi és választási rendszeren túlmutató karizmatikus legitimációt biztosít az autokrata vezető számára. Valóban, a populista autokraták hétköznapi politikusok helyett sokkal inkább szent misszióval bíró posztmodern próféták. Ehhez kapcsolódóan a populizmus folyamatos válságkonstruálása és a politika rendkívüli állapotként való értelmezése kifejezetten vonzó lehet az autokrata vezetők számára, hiszen ezáltal legitimálhatják magukat, mint erőskezű vezetők. A populizmus tehát végső soron az autokratikus autoinvesztitúra paradigmatikus esetének is tekinthető.

Láthatjuk, hogy a választások és az egyéb plebiszciter technikák milyen kiemelt jelentőséggel bírnak a populista autokráciák számára. Ezeken a kvázi-demokratikus, manipulált mozzanatokon keresztül történik ugyanis a populista vezető felavatása és (újbóli) hatalomba iktatása, a nép által történő elismertetése. Míg a demokráciák esetében a politikai verseny a békés hatalomváltás lehetőségét teszi lehetővé, ezért a leendő győztes kiléte mindig bizonytalan a fair és szisztematikusan nem torzított politikai arénában, addig a választási autokráciák célja éppen a hatalomban maradás bizonytalanságának minimalizálása. Ezért az átalakított politikai intézményrend- 


\section{TANULMÁNY}

szer - és különösen a választások - elsődleges feladatává az válik, hogy korlátozzák, vagy akár megszüntessék a hatalom elvesztésének kockázatát. Ezért „a választási autokráciák az autoriter politika intézményrendszerének kialakításában különböznek a többi nem demokratikus rendszertől. Létrehozzák a formális képviseleti intézmények teljes készletét, melyeket a liberális demokráciához társítunk - miközben manipulatív stratégiák széles tárházát telepítik, megelőzendő ezen intézmények hatékony múködését” (Schedler 2013: 54). A populista autokráciák, akárcsak a választási autokráciák általában, a demokratikus látszat mögötti autokratikus uralmat a represszió, a kooptálás és a legitimáció különféle stratégiáival tartják fent. A változatos intézményes manipulációk a hatalom aspektusában a törvényhozás, az igazságszolgáltatás és a decentralizáció, a pluralizmus korlátozása terén pedig a választások, a pártok, a média és a civil társadalom dimenzióiban jelentkeznek, és a dahli poliarchia kritériumrendszeréhez hasonlóan értelmezett „demokratikus választás láncolatának” megtörését célozzák. Ebben a demokrácia elemei „egy metaforikus láncolatot alkotnak, amely feladata, hogy a rendszeresen megtartott választások betöltsék a valódi demokratikus választás ígéretét, és amely mint egy valóságos lánc, csak addig létezik, ameddig az elemek közötti összes kapcsolat megmarad teljesnek és töretlennek" (Schedler 2002: 40). A láncolat megtörését és a verseny unfair jellegét biztosítani hivatott manipulációs technikák egy folyamatosan bővülő eszköztárt jelentenek, amely az ellenzéki szereplőknek a választási küzdelem színtereihez való hozzáférésének korlátozásától, vagy az ellenzéki pártok fragmentálásától és „felforgatásától" a választók megfélemlítésén és megvásárlásán át egészen a garrymandering, és egyéb választástechnikai és választójogi intézményes trükközésig számtalan, sok esetben innovatív formát ölthet.

A fó állításom ehhez kapcsolódóan az, hogy ezeket a hardver jellegű eszközöket kiválóan egészíti ki a demokrácia autokratikus értelmezéseként felfogott populizmus szoftvere. Az extrém módon polarizáló populizmus hatalomra kerülésekor sosincs ellenség-ínség: a továbbra is underdog pozícióból vívott élet-halál harc a formális és informális (háttérben ügyködő) globális, és az azokkal összefonódó, azokat kiszolgáló lokális ellenségek hálózatai ellen zajlanak. A végletekig moralizált politikai konfliktusok nyomán a populista kormányzás permanens kampánnyá alakul át, amelyben továbbra is központi szerep jut a válságnarratívának (Moffitt - Tormey 2014, Moffitt 2016, Körösényi et al. 2020). A hatalomra került populizmus legfőbb hatalmi eszközei az állam teljes elfoglalásával a fékek és ellensúlyok rendszerének felszámolása, a tömegklientúra-építés és a civil társadalom szisztematikus elnyomása, valamint a populista alkotmányozás, mind „társadalompolitikai, mind a politikai szabályok új készletének kialakítása értelmében" (Müller 2016: 62), amely a politikai játékteret intézményesített formában is a számára kedvező irányba billenti.

A populista autokrácia, mint az autokráciák rendszertani családjához (familia) tartozó posztmodern autokráciák kategóriájának (genus) paradigmatikus altípusa (species), szintén különösen magas ellenálló képességgel rendelkezhet. Az ilyen tí- 


\section{TANULMÁNY}

pusú rezsimek stabilitásának kulcsa abban az alkalmazkodóképességben és flexibilitásban rejlik, amellyel ügyesen manővereznek a stabilitásért felelős pillérek (represszió, kooptálás, legitimáció stratégiái), és az azokon belüli konkrét manipulációs technikák között. A stabilitás komplex jellege lehetővé teszi, hogy szükség esetén a különféle dimenziók terén módosulások és hangsúlyáthelyezések történhessenek, például az output legitimáció helyett az input (például populista) aspektusok kerüljenek előtérbe, vagy a legitimáció és kooptálás pillére helyett a represszió szintje fokozódjon. Mivel egy radikális, a modern autokráciákat idéző hatalmi fordulat túlságosan költséges lenne, a kvázi-demokratikus legitimációt biztosító manipulált, de többpárti választásokra és másfajta plebiszciter technikákra nélkülözhetetlen szerep hárul a posztmodern autokráciák számára, amelyekben a konszolidált politikai versenyt élet-halál harccá transzformáló és egyéb kognitív funkciókat ellátó populizmus központi szerepet tölthet be. Ezen felül a populizmus egy nagyon hatékony valóságformáló eszköz, amely segítségével akár rapid irányváltások vagy váratlan intézkedések is igazolhatóak, és amellyel az esetleges stabilizációs kihívások is könynyebben kezelhetőek, hiszen segítségével az állampolgárok politikai valóságképe válik megfelelően hajlíthatóvá. Ez utóbbi kiemelt jelentőségű, hiszen a barát-ellenség logika végletekig történő kiélezése nyomán létrejött szekértábor-logika ugyanis a mindenkori politikai tartalmat zárójelbe teszi, a lényeg az antagonisztikus szembenállás és a saját táborral (in-group) és vezetőjével való puszta azonosulás lesz. Azaz a populista autokrácia - mint a posztmodern autokráciák egy paradigmatikus típusa - jelensége sokáig velünk maradhat, újabb és újabb feladatokat adva ezzel a múködésükkel foglalkozó kutatók számára.

\section{Összegzés}

A tanulmány során a globális demokráciakrízis, a populizmus és az új típusú autokráciák kapcsolatát vizsgáltam azzal az előfeltevéssel, hogy a világszerte tapasztalható, szimultán térhódításuk összefügg az egymást kiegészítő és kölcsönösen erősítő természetükkel. Állításom szerint a populizmus lehet az a kapocs, amelyik nem csupán leírja, és megfelelő elméleti keretbe ágyazza, hanem sok tekintetben magyarázza is a képviseleti demokráciák sokasodó kihívásait és a posztmodern autokráciák mindennapi működését. Az állítás érvényessége persze nagyban függ attól, hogy mit értünk populizmus és demokrácia kifejezések alatt, illetve azzal, hogy miképpen viszonyulunk a liberális demokráciák többségellenes intézményeihez. Előzetes megfontolásaim szerint a populizmus politikai fogalmával való azonosítása nem túlságosan hasznos, amely magát a terminológiát teszi redundánssá és feleslegessé. Másfelől, a populizmus-kutatás mainstream (minimalista) megközelítése, amely a populizmust a liberális demokrácia populista-demokratikus pilléreként értelmezi, szinte reflektálatlan marad a populizmus éles antipluralizmusára és politikai kizárá- 


\section{TANULMÁNY}

sára. Így az ebben az esetben, végeredményben egy demagógiaszerű fogalom marad, amely továbbra is túl széles ahhoz, hogy érdemben használni lehessen, és amely használatával nehéz megmondani, hogy pontosan kik is a populisták és kik nem. Ezeken túlmenően a demokrácia meghatározásakor abból a normatív alapállásból indultam ki, miszerint a demokrácia választásos és szelektív poliarchia, amelynek középpontjában a népszuverenitás és a hatalom korlátozása áll. Ebből következően a demokráciákban a nép identitása mindig csupán ideiglenesen meghatározott és a hatalom helye üres, azaz a politika pluralista felfogása alapvető nélkülözhetetlen elem. Röviden tehát a demokrácia egy olyan speciális színpadnak tekinthető, amelyben a pluralitás elfogadása - mint az egyének diverzitása, mint különféle legitim politikai aktorok küzdelme, valamint a hatalom megosztottsága - kulcsfontosságú.

Szemben ezekkel a demokratikus elvekkel, a populizmus az antipluralizmus moralizált formáját és a politikai kizárást testesíti meg, mindenekelőtt a homogénnek képzelt nép egységes akaratának és a közjó meghatározásának kisajátítására törekvő, megcáfolhatatlan morális képviseleti igénye miatt. Éppen ezért, a populizmus mint egy trójai faló, különösen veszélyes a demokráciákra nézve. Ebben az értelemben az elitkritika szükséges, de önmagában elégtelen feltétele annak, hogy valakit populistának tartsunk, hiszen az utóbbiak nem csupán antielitisták, hanem antipluralisták is, azt állítva, hogy „ők, és csakis ők képviselik igaz módon a népet”. A populisták állítása végső soron tautologikus, hiszen azt mondják, „hogyha nem értesz egyet a népakarattal, ahogy én interpretálom, és nem ismersz el engem az ezt megfogalmazni képes egyetlen vezetőnek, akkor nem is tartozol a (valódi) néphez". Azaz a valódi nép attól autentikus, mert az egyetlen legitim vezért ismeri el, aki attól legitim, mert a nép őt ismeri el. A populisták ezzel megpróbálnak egy végső és tartalmilag meghatározott népakarat-értelmezéssel és a politikai közösség organikus egységének képzetéhez kapcsolódó identitással végérvényesen lezárni az ezekhez kapcsolódó, eredendően vég nélküli demokratikus folyamatokat. Pontosan ez a fajta, a hatalom és a nép legitim identitásának üres helyét bezárni akaró logika jelenti a populizmus lényegét, amely ezért a demokrácia és a képviselet egy autokratikus értelmezése, nem pedig a demokrácia egyik pillére, ahogyan azt a fősodratú populizmus-kutatás állítja. A populista képviselet (represent) inkább megtestesítés (presentation vagy embodiment), semmint demokratikus képviselet, ahogyan az akklamáció sem tartozik a Sartori-féle demokratikus beiktatás (szabad, versengő és tiszta választások) kategóriájához, hanem az autokráciák egy speciális autoinvesztitúra által jellemezhető válfajához tartozik, amelyben valaki saját magát kiáltja ki vezetőnek és a népakarat egyetlen legitim megtestesítőjének, miközben minden más politikai riválistól megtagadja a politikai közösség legitim képviseletének jogát. Más szavakkal a populisták formálisan a nép nevében, ugyanakkor tartalmilag a nép nélkül szeretnék a hatalmat gyakorolni. Az antagonisztikus konfliktusok gerjesztésével és polarizáló politizálással egyszerre képesek az állampolgárokat depolitizálni és paszszivitásra kárhoztatni, valamint a politika iránti általános neheztelésüket erősíteni 


\section{TANULMÁNY}

azáltal, hogy növelik a negatív percepciókat és attitűdöket a demokrácia mindennapi müködésével kapcsolatban, ugyanakkor, egy jobb élet reményében a tömegek repolitizálására és aktivizálására is alkalmasak lehetnek. Ezért a populizmus egyszerre idézi elő és testesíti meg a globális demokráciakrízist, azaz egyszerre következménye és oka az utóbbinak.

Végezetül amellett érveltem, hogy a populizmus nem csupán a globális demokráciakrízis, hanem az új típusú autokráciák számtalan aspektusának leírására és megfelelő elméleti keretbe helyezésére, illetve a mindennapi működésük magyarázatára is alkalmasnak tűnik. Elsősorban azért, mivel a posztmodern autokráciák szisztematikusan eltorzított, így korlátozottan versengő jellegét, valamint a rendszeren belüli újabb és újabb autokratikus tendenciákat elfedheti és legitimálhatja, azaz a populizmus a hatalomgyakorlás autokratikus természetét fügefalevél módjára képes eltakarni. A posztmodern autokráciák azért, hogy minimalizálják vagy teljesen kiiktassák a versengés kockázatait, egyrészt szisztematikusan korlátozzák és a maguk javára torzítják a versenyfeltételeket, másfelől gyakran élnek a számukra hasznos populista demokrácia- és képviselet-felfogással. Következésképpen, az autokratikus eszköztárat (hardware) gyakran kiegészítik egy kvázi-demokratikus szoftverrel, amely igazolhatja a morális és politikai egyenlőtlenségeket. Ezáltal $a$ populista autokráciák a posztmodern autokráciák egy paradigmatikus típusát adják, létrehozva egy sajátos, populista autokráciát kiteljesítő szimbiózist, amelyben a trükkös autoinvesztitúra a populizmus nyelvezetével és politikai következményeivel van elrejtve. A populizmus a posztmodern autokráciák stabilizációs rendszerének minden dimenziójában (represszió, kooptálás, legitimáció) kiemelt szerepet tölthet be. A populista autokráciák stabilitásának kulcsa abban az alkalmazkodóképességben és flexibilitásban rejlik, amellyel ügyesen manővereznek a stabilitásért felelős pillérek (represszió, kooptálás, legitimáció stratégiái), és az azokon belüli konkrét manipulációs technikák között. Állításom szerint a populizmus hatékonyan fejleszti az autokráciák ellenálló képességét, erősítve a stabilitás komplex jellegét, és azt, hogy szükség esetén a különféle dimenziók terén módosulások és hangsúlyáthelyezések történhessenek. Ezen felül a populizmus egy nagyon hatékony valóságformáló eszköz, amely segítségével akár rapid irányváltások vagy váratlan intézkedések is igazolhatóak, és amellyel az esetleges stabilizációs kihívások is könnyebben kezelhetőek, hiszen segítségével az állampolgárok politikai valóságképe válik megfelelően hajlíthatóvá. Ez utóbbi kiemelt jelentőségű, hiszen a barát-ellenség logika végletekig történő kiélezése nyomán létrejött szekértábor-logika ugyanis a mindenkori politikai tartalmat zárójelbe teszi, a lényeg az antagonisztikus szembenállás és a saját táborral (in-group) és vezetőjével való puszta azonosulás lesz.

Zárásképpen a kutatás folytatásának lehetséges empirikus irányait szeretném jelezni. A továbbiakban elsősorban az összehasonlító aspektusok kaphatnak nagyobb hangsúlyt. Ebben az esetben a populista autokráciák (mint például a kortárs Oroszország, Törökország, Magyarország, Szerbia, Venezuela, Fülöp-szigetek) vagy 


\section{TANULMÁNY}

az egyelőre demokratikus rezsimek többé-kevésbé „magányos farkas” jellegű populista autokratái (mint Donald Trump, Jair Bolsonaro, Marine Le Pen, Benjamin Netanyahu, Jarosław Kaczyński, Janez Janša) jelenthetik a vizsgálatok tárgyát. Különösen sokat jelentene egy-egy olyan eset alaposabb feltárása, amelyben a populizmus „kompként” szolgálja végig egy ország teljes körű rezsimváltását: azaz előbb a demokráciakrízis egyes elemeit akkumulálva és akcelerálva afféle trójai falóként készíti elő és aktívan segíti az autokratikus fordulatot, majd a későbbiekben a posztmodern autokrácia fügefaleveleként leplezi, szükség esetén pedig igazolja a korlátozott politikai versenyt, valamint az autokratikus hatalomgyakorlás és politikai berendezkedés jellegét. Sajnálatos módon a mai világ számtalan potenciális empirikus példával szolgálhat ezek kapcsán.

\section{Irodalom}

Abts, K. - Rummens, S. (2007): Populism versus Democracy. Political Studies, 55, 405-424. https://doi.org/10.1111\%2Fj.1467-9248.2007.00657.x

Ágh A. (2017): A politika alulnézetben. A politika világa a nyugat-európai demokráciában. Budapest, Noran Libro Kiadó

Ágh A. (2018): Generációs metszetek Magyarországon. Az európai kihívás és a keletközép-európai válasz. In: Antal A. (szerk.): Mozgalmi társadalom. Budapest, Noran Libro Kiadó, 11-54.

Antal A. (2017): A populista demokrácia természete. Realizmus és utópia határán. Budapest, Napvilág Kiadó

Antal A. (szerk.) (2019): Neoliberális hegemónia Magyarországon: Elemzés és kritika. Budapest, Noran Libro Kiadó

Armony, A. C. - Schamis, H. E. (2005): Babel in democratization studies. Journal of Democracy, 16(4): 113-128. https://doi.org/10.1353/jod.2005.0055

Backes,U.-Steffen K.(szerk.) (2015):Ideocraciesin Comparison Legitimation-Cooptation - Repression. London, Routledge https://doi.org/10.4324/9781315725925

Barth A. - Kopasz M. (2019): Legitimációs stratégiák hibrid rezsimekben. Szingapúr mint legitimációs puzzle. In: Böcskei B. - Szabó A. (szerk.): Hibrid rezsimek. A politikatudomány X-aktái. Budapest, Napvilág Kiadó, 99-122.

Benedek I. (2019): Üdvözlet a győzőnek? A populizmus térhódítása: szükséges fordulat, múló korszellem vagy autoriter veszélyforrás? Jel-Kép, 2019/2: 26-44. DOI: 10.20520/JEL-KEP.2019.2.27

Böcskei B. - Hajdú N. (2019): Demokráciák, szürke zónák, hibrid rezsimek - egy terminológiai Bábel megmászása. In: Böcskei B. - Szabó A. (szerk.): Hibrid rezsimek. A politikatudomány X-aktái. Budapest, Napvilág Kiadó, 17-34. 


\section{TANULMÁNY}

Böcskei B. - Szabó A. (szerk.) (2019): Hibrid rezsimek. A politikatudomány X-aktái. Budapest, Napvilág Kiadó

Bogaard, M. (2009): How to classify hybrid regimes? Defective democracy and electoral authoritarianism. Democratization, 16(2): 399-423. https://doi.org/10.1080/13510340902777800

Bozóki A. - Hegedűs D. (2017): A kívülről korlátozott hibrid rendszer. Az Orbán-rezsim a rendszertipológia tükrében. Politikatudományi Szemle, 26(2): 7-32.

Bruff, I. (2016): Neoliberalism and authoritarianism. In: Springer, S. - Birch, K. MacLeavy, J. (eds.): The Handbook of Neoliberalism. New York, Routledge, 107-117.

Bruszt, L. - Langbein, J. (2017): Varieties of dis-embedded liberalism. EU integration strategies in the Eastern peripheries of Europe. Journal of European Public Policy, 24(2): 297-315. https://doi.org/10.1080/13501763.2016.1264085

Bugaric, B. - Kuhelj, A. (2018): "Varieties of Populism in Europe: Is the Rule of Law in Danger? Hague Journal of Rule of Law, 10(1): 21-33. https://doi.org/10.1007/ s40803-018-0075-4

Bugaric, B. (2019): Central Europe's descent into autocracy: a constitutional analysis of authoritarian populism. International Journal of Constitutional Law, 17(2): 597-616. https://doi.org/10.1093/icon/moz032

Bunce, V. - Wolchik, S. (2011): Defeating Authoritarian Leaders in Postcommunist Countries. Cambridge, Cambridge University Press

Butler, I. (2018): Countering Populist Authoritarians: Where their support comes from and how to reverse their success. Berlin, Civil Liberties Union for Europe

Canovan, M. (1999): Trust the People! Populism and the Two Faces of Democracy. Political Studies, 47(1): 2-16. https://doi.org/10.1111/1467-9248.00184

Canovan, M. (2002): Taking Politics to the People: Populism as the Ideology of Democracy. In: Mény, Y. - Surel, Y. (eds.): Democracies and the Populist Challenge. Palgrave Macmillan, Basingstoke, Hampshire UK, 25-44.

Carothers, T. (2002): The End of the Trasition Paradigm. Journal of Democracy, 13(1): 5-21. DOI: $10.1353 /$ jod.2002.0003

Cassani, A. - Tomini, L. (2018): Reversing Regimes and Concepts: From Democratization to Autocratization. European Political Science 57(3): 687-716. https://doi.org/10.1057/s41304-018-0168-5

Cassani, A. (2014): Hybrid what? Partial consensus and persistent divergences in the analysis of hybrid regimes. International Political Science Review, 35(5): 542-558. https://doi.org/10.1177/0192512113495756 


\section{TANULMÁNY}

Cassani, A. (2017): Social services to claim legitimacy: comparing autocracies' performance. Contemporary Politics, 23(3): 348-368. https://doi.org/10.1080/ 13569775.2017.1304321

Collier, D. - Levitsky, S. (1997): Democracy with Adjectives: Conceptual Innovation in Comparative Research. World Politics, 49(3): 430-451. https://doi.org/10.1353/ wp.1997.0009

Crouch, C. (2004): Post-Democracy. Cambridge, Polity Press

Csizmadia E. (2016): A tranzitológiának vége, felejtsük el? Az átmenet tervezett intézményeitől a tervezetlen hibridizációig. Politikatudományi Szemle, 25(2): 135-153.

de la Torre, C. (szerk.) (2018): Routledge Handbook of Global Populism. London, Routledge

Debre, M. J. - Morgenbesser, L. (2017): Out of the shadows: autocratic regimes, election observation and legitimation. Contemporary Politics, 23(3): 328-347. https://doi.org/10.1080/13569775.2017.1304318

Diamond, L. (2002): Thinking about Hybrid Regimes. Journal of Democracy, 13(2): 2135. DOI: $10.1353 /$ jod.2002.0025

Diamond, L. (2003): The Illusion of Liberal Autocracy. Journal of Democracy, 14(4): 167-171. DOI: 10.1353/jod.2003.0070

Diamond, L. (2019): The Road to Digital Unfreedom: The Threat of Postmodern Totalitarianism. Journal of Democracy, 30(1): 20-24. DOI: 10.1353/jod.2019.0001

Dukalskis, A. - Gerschewski, J. (2017): What Autocracies Say (And What Citizens Hear): Proposing Four Mechanisms of Autocratic Legitimation. Contemporary Politics, 23(3): 251-268. https://doi.org/10.1080/13569775.2017.1304320

Foa, E. S. (2018): Modernization and Authoritarianism. Journal of Democracy, 18(3): 129-140. DOI: 10.1353/jod.2018.0050

Frantz, E. - Kendall-Taylor, A. (2014): A dictator's toolkit: understanding how cooptation affects repression in autocracies. Journal of Peace Research, 51(3): 332346. https://doi.org/10.1177/0022343313519808

Fukuyama, F. (1992): The End of History and the Last Man. New York, Avon Books

Gerschewski, J. - Schmotz, A. (2011): Contrary or contradictory? Autocracies and democracies between dichotomy and gradation. Reykjavik, 6th ECPR General Conference

Gerschewski, J. (2013): The three pillars of stability: legitimation, repression, and co-optation in autocratic regimes. Democratization, 20(1): 13-38. https://doi.org/10.1080/13510347.2013.738860 


\section{TANULMÁNY}

Gerschewski, J. (2018): Legitimacy in Autocracies: Oxymoron or Essential Feature? Perspectives on Politics, 16(3): 652-665. https://doi.org/10.1017/ S1537592717002183

Guriev, S. M. - Treisman, D. (2015): How Modern Dictators Survive: An Informational Theory of the New Authoritarianism. NBER Working Paper

Guriev, S. M. - Treisman, D. (2019): A Theory of Informational Autocracy. SSRN, April 3, 2019. DOI: $10.2139 /$ ssrn.3426238

Gyulai A. - Stein-Zalai J. (2016): Hibrid rezsimek és a szürke zóna: új válaszok a politikai rezsimek rendszertanának örök kérdéseire. Metszetek, 2016 (2): 42-59. DOI 10.18392/METSZ/2016/2/9

Hickel, J. (2016): Neoliberalism and the end of democracy. In: Springer, S. - Birch, K. MacLeavy, J. (szerk.): The Handbook of Neoliberalism. New York, Routledge, 142-151.

Huntington, S. P. (1991): The Third Wave: Democratization in the Late Twentieth Century. University of Oklahoma Press

Judis, J. B. (2016): The Populist Explosion: How the Great Recession Transformed American and European Politics. New York, Columbia Global Reports

Kaltwasser, C. R. - Taggart, P. -Ochoa Espejo, P. - Ostiguy, P. (eds.) (2017): The Oxford Handbook of Populism. Oxford, Oxford University Press

Karl, T. L. (1995): The Hybrid Regimes of Central America. Journal of Democracy, 6(3): 72-86. DOI: 10.1353/jod.1995.0049

Kis J. (2019): Demokráciából autokráciába. Politikatudományi Szemle, 28(1): 45-73. DOI: https://doi.org/10.30718/POLTUD.HU.2019.1.45

Körösényi A. - Gyulai A. (2019): A hibridrezsim-fogalom korlátai és egy alternatív megközelítés: a plebiszciter vezérdemokrácia. In: Böcskei B. - Szabó A. (szerk.): Hibrid rezsimek. A politikatudomány X-aktái. Budapest, Napvilág Kiadó, 159-177.

Körösényi A. - Illés G. - Gyulai A. (2020): The Orbán Regime: Plebiscitary Leader Democracy in the Making. London, Routledge

Laclau, E. (2011): A populista ész. Budapest, Noran Libro Kiadó

Lefort, C. (1986): The Political Forms of Modern Society: Bureaucracy, Democracy, Totalitarianism. MIT Press

Lefort, C. (1988): Democracy and Political Theory. Cambridge, Polity

Levitsky, S. - Ziblatt, D. (2018): A demokráciák halála. Budapest, Kossuth Kiadó

Levitsky, S. - Way, L. A. (2002): The Rise of Competitive Authoritarianism. Journal of Democracy, 13(1): 51-65. DOI: 10.1353/jod.2002.0026

Levitsky, s. - Way, L. A (2010): Competitive Authoritarianism. Hybrid Regimes After the Cold War. Cambridge, Cambridge University Press 


\section{TANULMÁNY}

Linz, J. - Stepan, A. (1996): Problems of democratic transition and consolidation Southern Europe, South America and post-communist Europe. Baltimore-London, The Johns Hopkins University Press

Lührmann, A. - Lindberg, S. I. (2019): A third wave of autocratization is here: what is new about it? Democratization, 26(7): 1095-1113. https://doi.org/10.1080/1351 0347.2019.1582029

Mair, P. (2002): Populist Democracy vs Party Democracy. In: Mény, Y. - Surel, Y. (eds.): Democracies and the Populist Challenge. Palgrave Macmillan UK, Basingstoke, Hampshire, 89-98.

Mair, P. (2013): Ruling the Void? The Hollowing of Western Democracy. Verso

Manin, B. (1994): The methamorphoses of representative government. Economy and Society, 23(2): 133-171. https://doi.org/10.1080/03085149400000001

Manin, B. (1997): The principles of representative government. Cambridge, Cambridge University Press

Mazepus, H. (2017): What Makes Political Authorities Legitimate? Students' Ideas about Legitimacy in Five European Democracies and Hybrid Regimes. Contemporary Politics, 23(3): 306-327. https://doi.org/10.1080/13569775.2017.1306 762

Mény, Y. - Surel, Y. (eds.) (2002): Democracies and the Populist Challenge. Palgrave Macmillan UK, Basingstoke, Hampshire

Merkel, W. (2004): Embedded and Defective Democracies. Democratization, 11(5): 3358. https://doi.org/10.1080/13510340412331304598

Merkel, W. (2014): Is capitalism compatible with democracy? Zeitschrift Für Vergleichende Politikwissenschaft, 8(2): 109-128. D0I 10.1007/s12286-014-0199-4

Moffitt, B. - Tormey, S. (2014): Rethinking Populism: Politics, Mediatisation and Political Style. Political Studies, 62(2): 381-397. https://doi.org/10.1111/1467-9248.12032

Moffitt, B. (2016): The Global Rise of Populism. Performance, Political Style, and Representation. Stanford, Stanford University Press

Morgenbesser, L. (2017): The Autocratic Mandate: Elections, Legitimacy, and Regime Stability in Singapore. The Pacific Review, 30(2): 205-231. https://doi.org/10.1080 /09512748.2016.1201134

Morlino, L. (2009): Are there hybrid regimes? Or are they just an optical illusion? European Political Science Review, 1(2): 273-296. https://doi.org/10.1017/ S1755773909000198

Mouffe, Ch. (1993): The Return of the Political. New York-London, Verso

Mouffe, Ch. (2018): For a Left Populism. New York-London, Verso, 89-93. 


\section{TANULMÁNY}

Mudde, C. - Rovira Kaltwasser, Cristóbal (2017): Populism: a very short introduction. New York, Oxford University Press

Mudde, C. (2004): The Populist Zeitgeist. Government and Opposition, 39(4): 541563. https://doi.org/10.1111/j.1477-7053.2004.00135.x

Müller, Jan-Werner (2016): What is Populism? University of Pennsylvania Press

Norris, P. - Inglehart, R. (2019): Cultural Backlash: Trump, Brexit, and Authoritarian Populism. Cambridge, Cambridge University Press

O’Donnell, G. (1994): Delegative Democracy. Journal of Democracy, 5(1): 55-69. DOI: 10.1353/jod.1994.0010

O’Donnell, G. (1996): Illusions about Consolidation. Journal of Democracy, 7(2): 34-51. DOI: $10.1353 /$ jod.1996.0034.

Ottaway, M. (2003): Democracy Challenged: The Rise of Semi-Authoritarianism. Washington, Carnegie Endowment for International Peace

Papadopoulos, Y. (2002): Populism, the Democratic Question, and Contemporary Governance. In: Mény, Y. - Surel, Y. (szerk.) (2002): Democracies and the Populist Challenge. Palgrave Macmillan UK, Basingstoke, Hampshire, 45-61.

Pappas, T. S. (2014): Populist Democracies: Post-Authoritarian Greece and Post-Communist Hungary. Government and Opposition, 49(1): 1-23. https://doi.org/10.1017/ gov.2013.21

Pappas, T. S. (2018): How to Tell Nativists from Populists. Journal of Democracy, 29(1): 148-152. DOI: $10.1353 /$ jod.2018.0012

Patkós V. (2017): Politikai polarizáció és gazdasági sikertelenség az európai demokráciákban. Politikatudományi Szemle, 26(4): 29-52.

Piketty, T. (2014): Capital in the Twenty-First Century. Harvard University Press

Rancière, J. (1999): Dis-Agreement. University of Minnesota Press

Reybrouck, David Van (2010): A populizmus védelmében. Budapest, Gondolat Kiadói Kör

Reybrouck, David Van (2016): Against Elections - The Case for Democracy. Random House UK.

Roberts, K. (2014): Democracy, Free Markets, and the Rightist Dilemma in Latin America. In: Juan Pablo Luna - Kaltwasser, Cristóbal Rovira (eds.) (2014): The Resilience of the Latin American Right. Baltimore, Johns Hopkins University Press, 25-48.

Rodrik, D. (2000): How Far Will International Economic Integration Go? Journal of Economic Perspectives, 14(1): 177-186. DOI: 10.1257/jep.14.1.177.

Rosanvallon, P. (2008) Counter-Democracy. Politics in an Age of Distrust. Cambridge, Cambridge University Press 


\section{TANULMÁNY}

Sartori, G. (1984): Guidelines for Concept Analysis. In: Giovanni Sartori (ed.): Social Science Concepts: A Systematic Analysis, Sage, Beverly Hills, 15-71.

Sartori, G. (1999): Demokrácia. Budapest, Osiris

Schedler, A. (2002): Elections Without Democracy: The menu of Manipulation. Journal of Democracy, 13(2): 36-50. DOI: 10.1353/jod.2002.0031.

Schedler, A. (2013): The politics of uncertainty. Sustaining and subverting electoral authoritarianism. Oxford, Oxford University Press

Schmitt, C. (1988): The Crisis of Parliamentary Democracy. MIT Press

Springer, S. - Birch, K. - MacLeavy, J. (2016): An introduction to neoliberalism. In: Springer, S. - Birch, K. - MacLeavy, J. (eds.) (2016): The Handbook of Neoliberalism. New York, Routledge, 1-14.

Standing, Guy (2011): The precariat : the new dangerous class. London-New York, Bloomsbury Academic

Szűcs Z. G. (2019): Milyen politikai kötelezettségeink vannak egy hibrid rezsimmel szemben? In: Böcske B. - Szabó A. (szerk.): Hibrid rezsimek. A politikatudomány X-aktái. Budapest, Napvilág Kiadó, 123-140.

Tallár F. (2017): Populizmusok és demokráciák, avagy a politika újraácsolt színpada. Politikatudományi Szemle, 2017 (1): 107-131.

Tóth G. A. (2016): Demokrácia és diktatúra között: az autoritarizmus. Fundamentum, 2016 (2-4): 5-18.

Unger A. (2018): A választás mint rendszerkarakterisztikus intézmény. Fundamentum, 2018 (2-3): 5-16.

Urbinati, N. (1998): Democracy and Populism. Constellations, 5(2): 110-124. https://doi.org/10.1111/1467-8675.00080.

Urbinati, N. (2013): The Populist Phenomenon. Raisons politiques, 2013/3: 137-154. https://doi.org/10.3917/rai.051.0137.

von Haldenwang, C. (2017): The relevance of legitimation - a new framework for analysis. Contemporary Politics, 23(3): 269-286. https://doi.org/10.1080/135697 75.2017.1304322

von Soest, C - Grauvogel, Julia (2017): Identity, procedures and performance: how authoritarian regimes legitimize their rule. Contemporary Politics, 23(3): 287-305. https://doi.org/10.1080/13569775.2017.1304319

Weyland, K. (1996): Neopopulism and Neoliberalism in Latin America: Unexpected Affinities. Studies in Comparative International Development, 31(3): 3-31. https://doi.org/10.1007/BF02738987

Whitehead, L. (2001): Demokratizálódás. Elmélet és tapasztalat. Budapest, Kairosz Kiadó 


\section{TANULMÁNY}

Wolin, S. (2008): Democracy Incorporated: Managed Democracy and the Specter of Inverted Totalitarianism. Princeton, Princeton University Press

Zakaria, F. (1997): The Rise of Illiberal Democracy. Foreign Affairs, 76(6): 22-43. DOI: $10.2307 / 20048274$. 